\title{
Epigenetics: A key paradigm in reproductive health
}

\author{
Neha Bunkar ${ }^{1}$, Neelam Pathak ${ }^{1,2}$, Nirmal Kumar Lohiya ${ }^{2}$, Pradyumna Kumar Mishra ${ }^{1,3}$ \\ ${ }^{1}$ Translational Research Laboratory, School of Biological Sciences, Dr. Hari Singh Central University, Sagar; ${ }^{2}$ Reproductive Physiology Laboratory, Centre \\ for Advanced Studies, University of Rajasthan, Jaipur, ${ }^{3}$ Department of Molecular Biology, National Institute for Research in Environmental Health \\ (ICMR), Bhopal, India
}

It is well established that there is a heritable element of susceptibility to chronic human ailments, yet there is compelling evidence that some components of such heritability are transmitted through non-genetic factors. Due to the complexity of reproductive processes, identifying the inheritance patterns of these factors is not easy. But little doubt exists that besides the genomic backbone, a range of epigenetic cues affect our genetic programme. The inter-generational transmission of epigenetic marks is believed to operate via four principal means that dramatically differ in their information content: DNA methylation, histone modifications, microRNAs and nucleosome positioning. These epigenetic signatures influence the cellular machinery through positive and negative feedback mechanisms either alone or interactively. Understanding how these mechanisms work to activate or deactivate parts of our genetic programme not only on a day-to-day basis but also over generations is an important area of reproductive health research.

Keywords: DNA methylation; Epigenomics; Histone code; MicroRNAs

\section{Introduction}

Epigenetic aberrations have been conjectured to be highly relevant to sexual and reproductive health, as they account for the interactive relationship among the genomic landscape, gene environment interactions and disease phenotype. Novel insights into aetiologies of complex non-Mendelian disease traits have provoked a burgeoning interest in the field of reproductive epigenetics. How a range of epigenetic mechanisms can differentially influence the male and female germ line and developmental process is being closely scrutinized. Of late, the subtle and elegant modulation of fidelity of transmissible heritable characteristics through epigenetic reprogramming has also received wider scientific attention. Developmental activation and deactivation of epigenetic signatures at the pre-implantation phase

Received: Jan 3, 2016 · Revised: Feb 6, 2016 · Accepted: Mar 16, 2016 Corresponding author: Pradyumna Kumar Mishra

Department of Molecular Biology, National Institute for Research in Environmental Health (ICMR), Kamla Nehru Hospital Building (GMC Campus), Bhopal 462001 (MP), India

Tel: +91-755-2533106 Fax: +91-755-2533976E-mail: pkm_8bh@yahoo.co.uk

This is an Open Access article distributed under the terms of the Creative Commons Attribution Non-Commercial License (http://creativecommons.org/licenses/by-nc/4.0/) which permits unrestricted non-commercial use, distribution, and reproduction in any medium, provided the original work is properly cited. provides putative links between assisted reproductive technologies and imprinting disorders. Occurrence of imprinting errors disrupts placental growth and development in assisted conception procedures.

It is important to understand how epigenetic information is established and regulated in the parental germline and how epigenetic inheritance takes place. This crucial knowledge may be of help to determine the connection between environmentally manipulated epigenetic alterations and development of the organism. It has often been argued that most epigenetic modification, by whatever mechanism, is erased with each new generation, during gametogenesis and after fertilization. DNA methylation, histone modification, microRNA (miRNA) expression, and nucleosome positioning are the four basic modes driving the path of development (Figure 1). Epigenetic control systems generally involve three types of proteins: "writers," "readers," and "erasers (Table 1)." Writers attach chemical marks, such as methyl groups (to DNA) or acetyl groups (to the histone proteins that DNA wraps around) [1]. Readers bind to these marks, thereby influencing gene expression; erasers remove the marks. The marks are passed down as cells divide, providing a sort of cellular memory to ensure that cell proliferation is effectively regulated. 


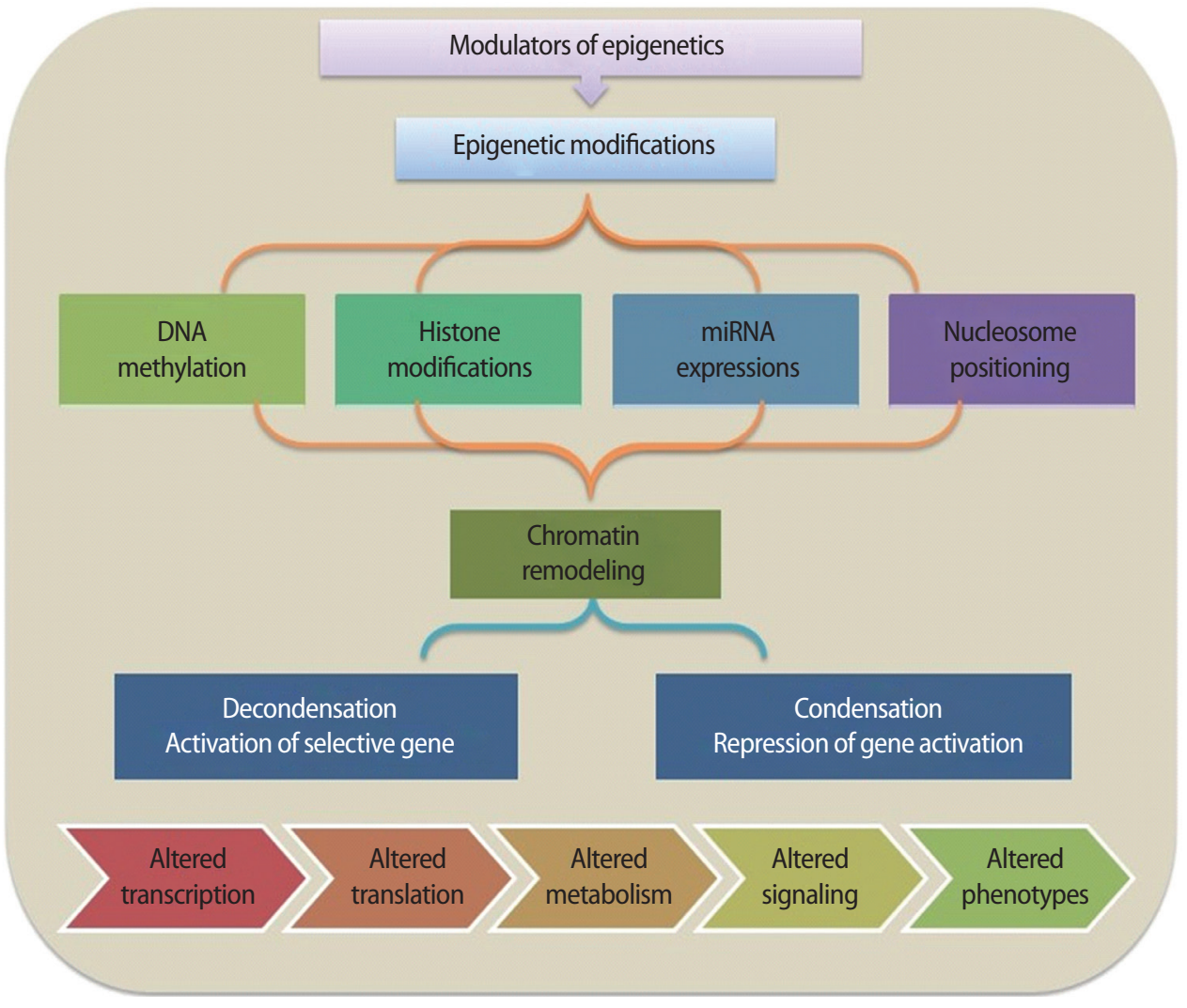

Figure 1. The basic mechanisms of epigenetic regulation. miRNA, microRNA.

\section{Epigenetic modifications 1) DNA methylation}

DNA methylation, a well-characterised epigenetic modification, is a heritable covalent modification and is binary in nature. Most methylation occurs at the number five carbon of the cytosine pyrimidine ring (5-methyl-cytosine or $5 \mathrm{mC}$ ) and represents less than $5 \%$ of all cytosines in our genomes. Genomic methylation patterns are propagated during cell division by DNA methyl-transferases (DNMT1, DNMT3A/B), which catalyse the transfer of a methyl group to DNA [2]. Five DNMT enzymes-DNMT1, DNMT2, DNMT3A, DNMT3B, and DNMT3L-actively regulate two different processes, that is, maintenance and de novo methylation activities [3]. One of the important sites for DNA methylation is $\mathrm{CpG}$-enriched regions associated with promoters called " $\mathrm{CpG}$ islands $[4,5]$." The majority of these sites are located in the promoter region and first exon of genes. DNMTs, along with other enzymes, can orchestrate gene silencing and maintain a repressive chromatin state. Once methylated, proteins such as MeCP2, MBD1, MBD2, and MBD4, which have a methyl-binding domain (MBD), bind to the DNA, which further impedes recruitment of transcription factors to DNA, leading to abrogated gene expression [6]. Hypermethylation of DNA can also recruit histone deacetylase (HDAC), leading to inevitable alterations in gene expression $[7,8]$.
DNA demethylation, a related event that is equally important, converts methyl-cytosine into cytosine either actively or passively. The replication-independent active mechanism uses the ten-eleven translocation (TET) enzyme family (TET1, TET2, and TET3) to catalyse hydroxylation of $5 \mathrm{mC}$ followed by activation-induced cytidine deamination $[9,10]$. On the other hand, replication-dependent passive demethylation occurs during inadequate availability of global methyl donor S-adenosyl-L-methionine (SAM) or DNMTs-mediated demethylation in the presence of $\mathrm{Ca}^{2+}$ ions and reducing surroundings [11]. Thus, promoter hypermethylation causes gene silencing whereas promoter demethylation results in gene expression.

\section{2) Histone modifications}

Histones are the globular proteins that undergo posttranslational modification and alter regulation of gene expression, and DNA replication, recombination, and repair. While nucleosomes represent the primary step in the construction of higher-order chromatin structures [12], histones have a protruding charged 15-38 amino acid Nterminus ("histone tail") that influences nucleosome assembly into higher order chromatin structures. In its condensed state, chromatin remains in a folded configuration so that the nucleosomes are stacked, and hence, not readily accessible to gene activation. Howev- 
Table 1. Molecules involved in the process of epigenetic regulation

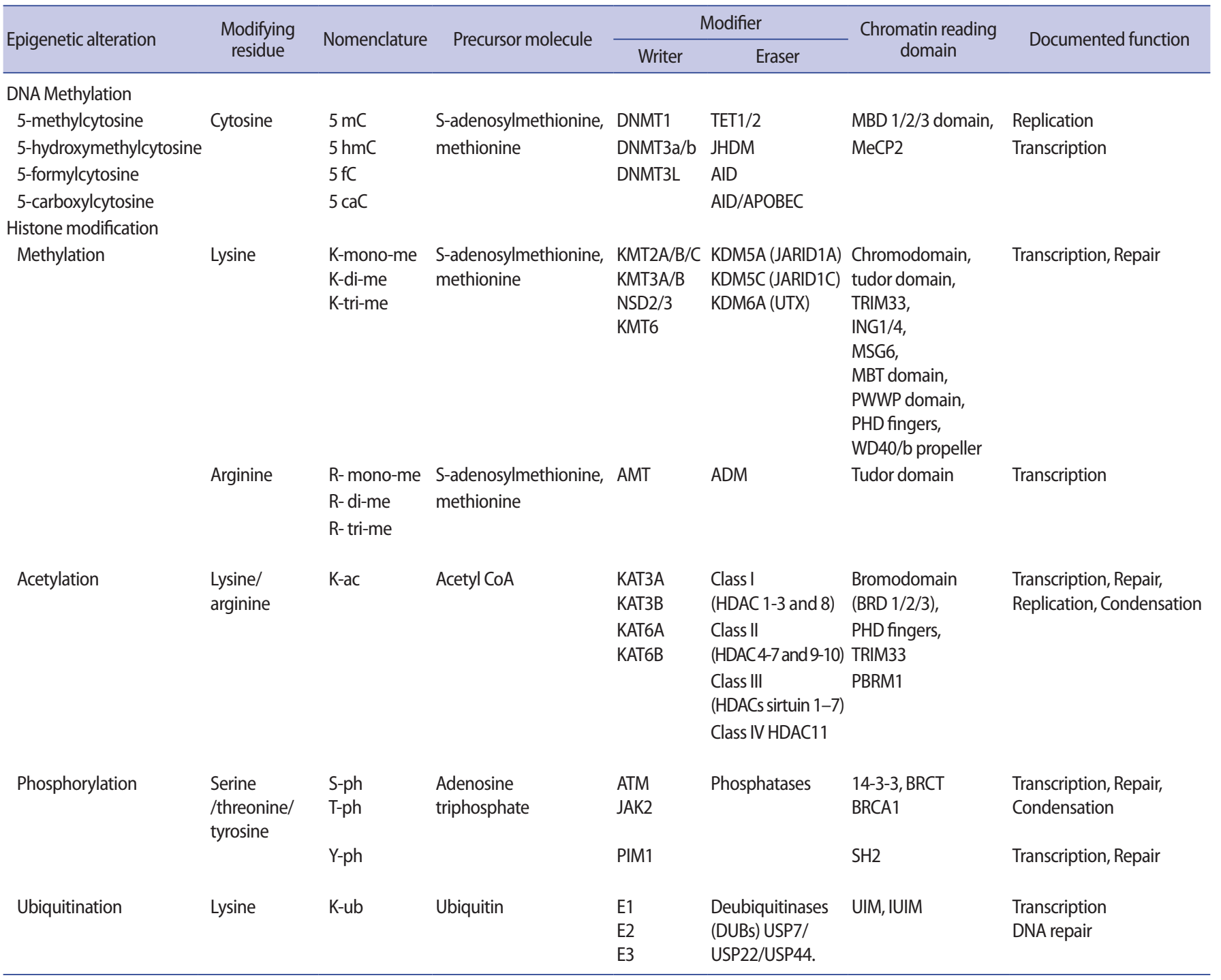

er, covalent modifications such as acetylation, methylation, phosphorylation, poly-ADP ribosylation, and ubiquitination on the long tails of histones alter histones-DNA interaction and higher order chromatin folding. These post-translational covalent modifications regulate the contact between the octamer core and DNA, and determine DNA accessibility to transcription factor complexes. The capability to accumulate information appears to dwell in the amino-terminal tails of the four core histones, which are exposed on the nucleosome surface and are subject to enzyme-catalysed post-translational modifications of select amino acids, including lysine acetylation, lysine and arginine methylation, serine or threonine phosphorylation, lysine ubiquitination, lysine sumoylation, or glutamine ADP ribosylation (Table 1). Epigenetic modification of the histone tail plays a key role in transcriptional regulation, DNA repair, DNA replication, alternative splicing, and chromosome condensation. With reference to its transcriptional state, the human genome can be approximately compartmentalised into actively transcribed euchromatin and transcriptionally inactive heterochromatin [13]. Euchromatin is characterised by high levels of acetylation and trimethylated H3K4, H3K36, and H3K79. On the other hand, heterochromatin is categorized by low levels of acetylation and elevated levels of H3K9, H3K27, and H4K20 methylation [14]. Interestingly, such dynamic modifications are actively added or removed by different histone-modifying enzymes (writers and erasers, respectively) that catalyse modification of specific amino acids with definite modifying groups in a site-specific manner to manage transcriptional control (Table 1). With specific modification, histones regulate the structural organization of chromatin by altering the electrostatic charge provided by the substituted group and facilitating recognition sites for different adaptor proteins (readers) such as proteins containing a bromodomain, which binds to the acetylated lysine inscriptions. 


\section{3) miRNA}

MicroRNAs (miRNA) are single-stranded RNAs approximately 21-23 nucleotides in length that are transcribed from DNA but not translated into proteins. These non-coding RNAs (ncRNAs) regulate several molecular pathways at the transcriptional or post-transcriptional level. miRNA genes primarily reside between genes (intergenic) or within introns (intronic) of genes and are transcribed to a primary miRNA (pri-miRNA) mediated by polymerase II or III [15]. The pri-miRNA is processed within the nuclear compartment to a precursor miRNA (pre-miRNA) by Drosha, a class 2 RNase III enzyme. Subsequently, the transport of pre-miRNAs to the cytoplasm is arbitrated by exportin-5. In the cytoplasmic region, they are processed further to develop into mature miRNAs by Dicer, an RNase III type protein, into 21-25 nucleotide double-stranded RNAs (dsRNAs) and loaded onto the Argonaute (Argo) protein to generate the effector RNA-induced silencing complex (RISC) [16]. RISC binds to mRNA, forming a RISC-mRNA complex on which miRNAs mediate sequence-specific recognition and binding, which further degrades or silences the target mRNA depending on the sequence complementarity. While the majority of researchers believe that miRNAs restrain translation, evidence that miRNAs can actually augment translation through alterations in the Argo component of the RISC has also been reported. Thus, while miRNAs appear to police translation in an inhibitory fashion, they may also boost translation in defined biological settings.

\section{4) Nucleosome positioning}

DNA packaging in nucleosomes might affect all stages of transcription, thereby regulating gene expression. The precise position of nucleosomes around the transcription start sites has an essential degree of control over the initiation of transcription [17]. Nucleosome positioning not only decides the accessibility of the transcription factors to their target DNA sequence but has also been reported to take part in shaping the methylation landscape. Besides transcription regulation, nucleosome occupancy also participates in directing meiotic recombination events. The precise function of nucleosomes is influenced by the incorporation of different histone variants that are incorporated into chromatin independently, outside the S-phase. Often linked with specific histone modifications, nucleosome remodelling machinery is also influenced by DNA methylation. Thus, the interaction among diverse epigenetic partners is often evident.

\section{Role in gametogenesis}

Gametogenesis occurs in a precisely defined microenvironment, and therefore molecular events during this process have to be strictly regulated to enable correct transmission of heritable information to subsequent generations. Primordial germ cells (PGCs) are the derivative source of both female and male germ cells that experience ge- nome-wide reprogramming during their relocation to the developing gonads. Reprogramming in the germ line is a crucial event to retune parent-specific epigenetic information, and is potentially vital for organization of sex-specific germ line development and identity [18]. The processes of development from germ cells to gametes and from gametes to embryos include dramatic cellular differentiation accompanied by drastic alteration in gene expression that occurs through tight regulation by genetic as well as epigenetic mechanisms [18]. These epigenetic mechanisms may be involved in checking meiosis and the terminal differentiation programme during gametogenesis, retaining information in gametes for the offspring and erasing improper marks in zygotes before the beginning of a new being. The chromatin structure of germ cells acts as a basic mechanism to preserve their unique self-renewal ability and block differentiation. In addition to chromatin remodelling, dynamic regulation of histone modifications and DNA methylation is also required to maintain germ cells' identity [19]. Developmental epigenetic characteristics are established in the process of gametogenesis and early embryogenesis (Figure 2).

\section{1) Spermatogenesis}

Male germ cells have compact nuclear DNA which are required for the transmission of the paternal genome to the oocyte. The highly compacted paternal DNA residing in the sperm head goes through extensive remodelling [20]. The process of spermatogenesis involves condensation of chromatin in the spermatid head prior to conversion of spermatids to spermatozoa [21]. The spermatids have a less compact genome in the early stages of spermatogenesis that is further compacted in the sperm genome by the substitution of histones by non-histone proteins. In the process of histone replacement, they are first replaced by transition proteins (TNP1 and TNP2) and eventually by protamines ( $\mathrm{P} 1$ and $\mathrm{P} 2$ ). This allows the protamines-bound sperm genome structure to compact 6 to 20 times more than the histonebound nuclear structure that makes it transcriptionally and translationally inert. Human spermatozoa are acknowledged to enclose a huge range of RNA molecules, including over 100 types of miRNA [22]. On the other hand, the mature sperm cells enclose only the mRNA and small RNAs that were present in the spermatids at the early phases of spermatogenesis. It was previously assumed that there is no participation of sperm transcriptome in embryo development but several recent studies have described the involvement of sperm genome organization as well as paternal transcriptome in early embryonic development. Moreover, chromatin of mature spermatozoa retains small amounts of histones, which is crucial in the differentiation and early development of the zygote. Surprisingly, the male pronucleus also displays elevated levels of histone acetylation, which supports higher transcription from the $S$ phase in the zygote stage and later. Demethylation in the PGCs results in activation of 


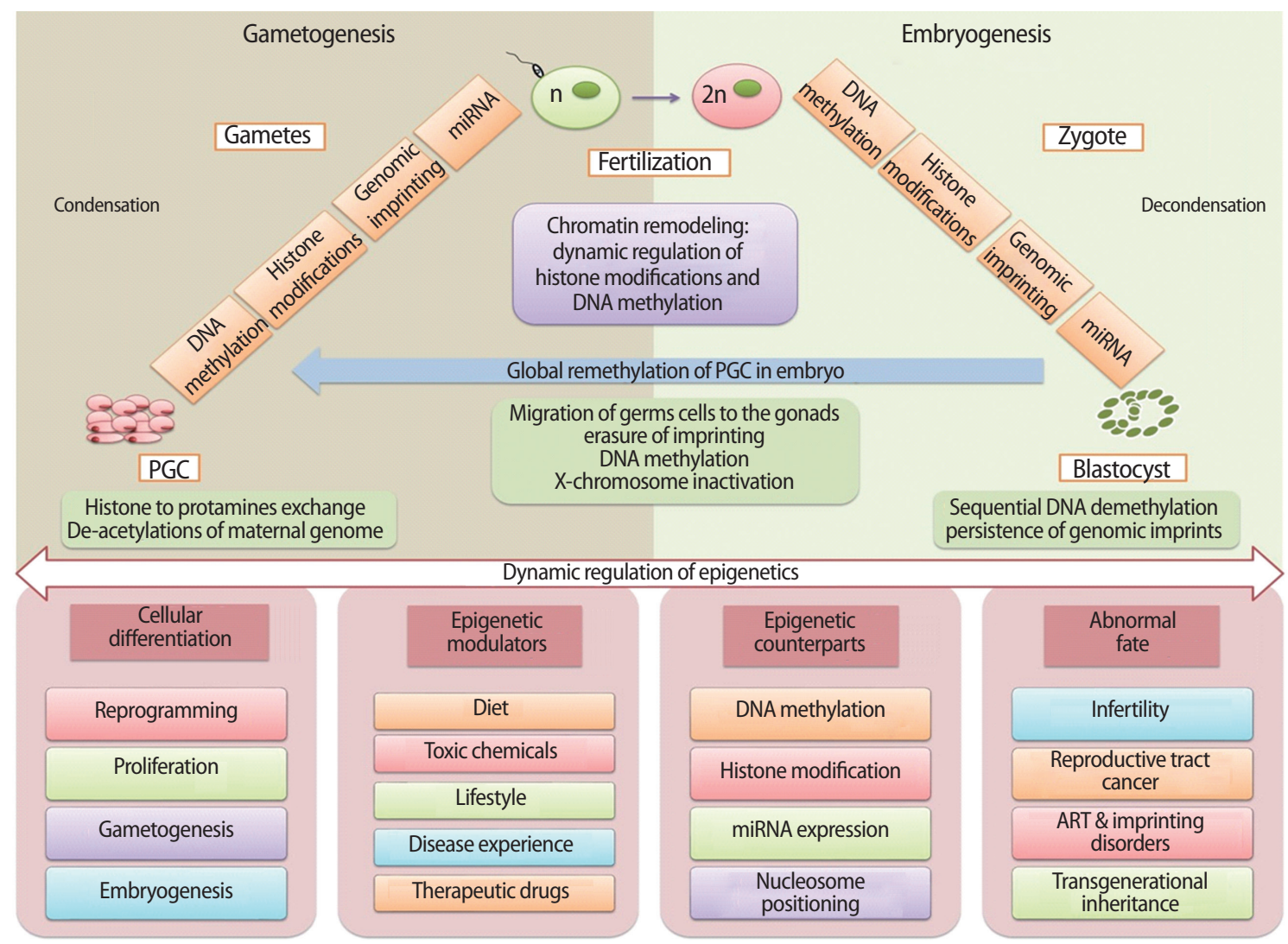

Figure 2. A summary of epigenetic mechanisms during gametogenesis and embryogenesis. PGC, primordial germ cell; ART, assisted reproductive technology.

genes: deleted in azoospermia-like (Dazl) and synaptonemal complex protein 3 ( (уср3), that are essential for gametogenesis [23]. This also regulates expression of testis-expressed (Tex19.1, Tex19.2) and Mili (also called Piwi-like 2) genes required to suppress any unmasked retrotransposon action and for a stable genome integrity [24]. miRNAs also regulate the transcriptional silencing in compact chromatincontaining elongating spermatids [25]. Dicer activity has been found to be crucial during male germ cell differentiation, as reported in Dicer knockout studies, which shows that early Dicer deletion results in damage accumulation and compromised spermatogenesis $[26,27]$. Increasing evidence supports the vital role played by small RNA-mediated RNA regulation in normal spermatogenesis and can affect male fertility if it fluctuates from the normal germline.

\section{2) Oogenesis}

The maternal DNA contained in the oocyte is bound by histones acquired during oocyte growth comprising post-translational modifications associated with stalled metaphase II. The major difference between the chromatin of oocyte and somatic nuclei is the deficiency of $\mathrm{H} 1$ linker histones in oocytes, which are replaced with a specific $\mathrm{H} 1$ variant whose role in early embryogenesis remains to be understood.
Histone methylations play important roles in the regulation of chromatin structure and gene expression during follicle maturation, especially for oocyte meiotic maturation. Euchromatin histone-lysine $\mathrm{N}$ methyl-transferase 2 (EHMT2) methylate H3K9me1 and H3K9me2 are crucial for early meiotic progression. It has been established that H3K9 me3 appears in growing oocytes from early antral follicles, increases subsequently during the growth phase, and is retained during oocyte meiotic maturation and activation [28,29]. However, at different developmental stages, sensitivity toward methylation of a diversity of histones including H3K4me, H3K4me2, and H3K4me3 has been found in granulosa cells of follicles as well as in oocytes from primary to antral-stage follicles [30]. In addition, histone ubiquitination may be another regulatory factor during follicle development. Ubiquitinated histone H2A is coupled with transcriptional silencing of large chromatin areas during meiosis in females. The production of gametes might require orderly and proper epigenetic reprogramming in premigratory and migratory germ cells for an appropriate epigenotype to support subsequent normal development. Genomic imprinting in the oocytes of females occurs after birth and is arrested at the diplotene stage of meiotic prophase $\mathrm{I}$, and is then completed by the de novo methylation process in the fully-grown oocyte stage. 


\section{Role in embryogenesis}

Organisms experience two developmental epigenetic reprogramming events: the first during gametogenesis and the second in the pre-implantation embryo [31]. Embryonic development includes an array of cell fate decisions to specify cell lineages that are established early during development, and that must be "maintained" through multiple cell divisions. It is increasingly evident that epigenetic inscriptions play a critical role in this cell memory during development [32]. It has long been appreciated that the parental pronuclei in mammalian zygotes and during preimplantation development acquire asymmetric epigenetic information, which include distribution of histone modifications and differences in the level of DNA methylation [33,34]. At this stage, the two parental genomes stay physically separate and undergo a diverse program of chromatin remodelling. Epigenetic restructuring is essential for transition of a totipotent zygote into pluripotent stem cells, leading to channelization to the multipotent lineage progenitor cells that finally reach the lineagespecific unipotent somatic cells. The stem cell transcriptome reprogramming by epigenetics is the ultimate control mechanism that provides stem cells with adaptability, flexibility, and versatility so they can modify their gene expression in response to developmental signals and differentiate into any cell (Figure 2). Here, the epigenetic modifiers play an important role to drive the information into cellspecific functional lineages [35]. Reversible DNA methylation and covalent histone modifications are two important agents in these mechanisms, where transient histone modifications provide shortterm flexibility in the early development of lineage-committed genes. Besides this, the various stages of development can be forced into long-term or permanent repression by DNA methylation, nucleosome positioning, and higher-order chromatin reorganization [36]. Recent reports from numerous laboratories have provided evidence that the recently fertilized oocyte acquires epigenetic signals from the sperm chromatin that are necessary for proper embryonic development [37].

After the fertilization of highly specialized ova and sperm, a wave of demethylation takes place in the zygote genome that continues till the 16-cell stage of development. The processes of epigenetic remodelling occur differently in the genome of each parent at this stage. The paternal genome goes through numerous cycles of decondensation by demethylation as well as protamines replacement with histones and histone variants. Following fertilization, the maternal genome completes meiosis and undergoes notably fewer epigenetic alterations as compared to the paternal genome. At the same time, imprinted regions escape demethylation cycles and maintain the specific epigenetic states of their parent of origin.

Reversible DNA methylation is an important epigenetic manipulator involved in a number of processes that maintain genome stability, organize mono-allelic expression of parentally imprinted genes, silence retrotransposons and confirm transcriptional silencing of genes on the inactive $\mathrm{X}$ chromosome. The two parental pronuclei have epigenetic asymmetry at the global levels of DNA methylation, as exhibited initially by high levels of DNA methylation $[33,38]$. These asymmetric and persistent epigenetic marks in the early stages of zygotic development and their effect on early embryonic development remain unclear. DNA methylation patterns are established in embryonic development by DNMT3A/B [39]. Precise DNA methylation patterns are required for regular development and lineage commitment. This causes the methylation of the entire genome while $\mathrm{CpG}$ islands are protected, which causes global repression and permits housekeeping gene expression in all cells. Although DNA methylation event is secondary, it possibly contributes an additional level of repression by providing long-term stability. However, it can be cut off both actively and passively at the episodes of reprogramming in PGCs and preimplantation embryos [40].

DNA demethylation is a very important player in epigenetic reprogramming of embryonic development and differentiation that determines cellular fate $[41,42]$. At the time of development, germline DNA methylation marks are globally removed in the blastocyst and a bimodal pattern is reestablished later during implantation when the entire genome gets methylated while $\mathrm{CpG}$ islands are protected. Just after fertilization, DNA-demethylation triggers the quiescent transcriptional machinery of the totipotent zygote which helps throughout germline reprogramming of the PGCs and eventually propels the pluripotent stem cells into lineage-restricted pathways. Both active and passive mechanisms of DNA demethylation mediate remodelling of the paternal genomes just after fertilization and before the initial zygotic divisions. Genome-wide active demethylation in the paternal pronucleus occurs before pronuclear fusion and first cleavage division [43]. Active demethylation involves extensive oxidation followed by passive loss over early cell divisions in the zygote [44]. Towards the 16-celled morula stage it experiences a replication-dependent loss of methylation (LOM) of the maternal pronucleus [43]. The delineation of the trophoectoderm from the inner cell mass at the blastocyst stage is also facilitated by hypomethylation in the promoter region of transcription factor E-74-like factor 5 [45]. It is thought that DNA-demethylation excites the onset of pluripotency in the zygote, subsequently triggers the expression of lineage-determining transcription factors and determines the embryo's segregation into the three embryonic germ layers.

The next major reprogramming event in the developing embryo happens in germ cell precursors known as PGCs. These cells originate directly from the blastocyst's pluripotent cells of the inner cell mass. They migrate to urogenital ridges during gastrulation, where they are reprogrammed by erasure of all pre-existing epigenetic modifications 
such as removal of maintained marks that were made during the preimplantation stage $[46,47]$. These mechanisms of regulation result in repression of somatic differentiation of genes and/or activation of genes concerned in preservation of specific germ cell identity [45]. These important phenomena therefore set up the sex-specific epigenetic profiles and transcriptional planning needed for the typical development of the germline and epigenetic inheritance regulation [48].

Reversible post-translational covalent histone modifications are crucial agents directing epigenetic regulation responsible for generation of differential transcriptional outcomes. Three different states of chromatin arrangement are seen depending on the occurrence and abundance of histone marks [49]. The first dynamic set of permissive marks, including tri-methylated histone H3 lysine 4 (H3K4me3), acetylated histone $\mathrm{H} 3$ lysine 9 ( $\mathrm{H} 3 \mathrm{~K} 9 \mathrm{ac}$ ) and acetylated histone $\mathrm{H} 4$ (H4ac) are found in the totipotent zygote and pluripotent stem cells. In somatic cells, lineage control genes are stably silenced by repressive histone modifications such as trimethylated histone $\mathrm{H} 3$ lysine 9 (H3K9me3) and trimethylated histone H3 lysine 27 (H3K27me3), which are a second set. The third state of chromatin arrangement is a more important and exclusive feature known as bivalent domains, found in key developmentally regulated genes. This domain contains active H3K4me3 and repressive H3K27me3 along with repressive H2AK119Ub1 marks and unmethylated CpG DNA regions (non$\mathrm{mCpG}$ [50]. These chromatin mechanisms acts as molecular switches maintained at a poised state amenable for specific transcriptional response upon receipt of differentiation cues [1].

Histone variants also have specific role in reprogramming of the epigenome. This occurs after fertilization and contributes to the differences between the two parental genomes. The male pronucleus has been observed with a $\mathrm{H} 3.3$ histone variant that possibly plays a role in directing or preventing other paternal-specific histone modifications. Modification of $\mathrm{H} 3.3$ has also been linked with developmental arrest due to mutations in lysine 27 of H3.3 and paternal pericentric heterochromatinization [51]. Although the exact functions of these H2A.X and H2A.Z variants remains unclear in early development, their deletion brings developmental arrest and failure of implantation.

Throughout the cellular stages and stages of development, a cell's nuclear architecture undergoes extensive dynamic changes such as in the level of chromatin compaction, accessibility by transcription factors and nucleosome positioning within specialized nuclear regions. This affects the degree of condensation of chromatin and nucleosomal organization that allows region-specific transcriptional profiles to be established during the course of cell commitment [1]. Probably the most complete understanding of involvement of miRNAs in paternal epigenetic inheritance come from the studies in Caenorhabditis elegans [52]. Studies involving identification of RNA sequencing of sperm RNA also suggest the possibility that these RNAs could contribute to epigenetic states in the early embryo [53].

Genomic imprinting can occur at hundreds of coding genes and regulatory ncRNAs. This is one of the important phenomena in epigenetics that regulate gene activity by preferential allele-specific gene expression. Simply imprinting mono-allelic DNA methylation marks can control the expression of imprinted genes, which are than maintained throughout development in a lineage- or tissue-specific manner [54]. This specific epigenetic regulation leads to expression of only one parental allele of a gene in such a way that some imprinted genes exhibit paternal expression whereas others exhibit maternal expression. These imprints are obtained in the process of gametogenesis when genome-wide epigenetic remodelling occurs, which must be maintained throughout preimplantation development where another wave of genome-wide epigenetic remodelling occurs [55]. The basic mechanism of this process is DNA methylation-based molecular arrangement, which regulates the establishment and maintenance of parental imprints all over early embryonic development and gametogenesis [56]. It is imperative to mention that methylated DNA regions are transcriptionally inactive, whereas unmethylated DNA regions are transcriptionally active. Methylated DNA regions are inhibited from expression by two processes, a methyl group attached to DNA can interfere in the binding to a particular transcription and methylated DNA regions can recruit MBD proteins mediating transcriptional repression. Genomic imprinting and epigenetic reprogramming in the context of DNA methylation is governed by two major waves of genome-wide demethylation and remethylation. First, in biparental genetic totipotent zygotic cells just after fertilization, and second in biparental methylation in the differentially methylated regions (DMRs) that are eliminated, imprinted methylation is reestablished in the germline for the next generation. That means imprinted DMRs remain unaffected at this first wave of genome-wide DNA demethylation and maintain parental imprints in the somatic tissues of the embryo throughout life. Animal studies suggest that those imprints that are established in growing oocytes during primordial to antral follicle transition will remain unaffected in some genes until just prior to ovulation; which could be vulnerable to ovarian stimulation. Deviations in proper epigenetic reprogramming such as disruption of imprinting in the germline can endorse heritable changes on transcription and diseases.

\section{Role in infertility}

Changes in the germline genome and epigenome can be a path for environmental and evolutionary adaptations. However, aberrant epigenetic remodelling of the germline is proposed as a potential mechanism by which gametogenesis can be compromised and can result in fertility and reproductive health-related problems. Emerging evidence suggests that genetic factors (cytogenetic abnormalities, DNA 
damage, disease status, hormonal abnormalities, effect of the micro environment, etc.) and environmental factors can have harmful effects on epigenetic arrangement during the process of implantation, placentation, and foetal growth. Therefore, even in a genetically normal individual, the environment can induce epimutations (a heritable change in gene expression that does not affect the definite base pair sequences of DNA) and can result in infertility and subfertility not only in the parent's germline but also potentially in the offspring.

\section{1) Male infertility}

Results of recent work have significantly improved our understanding of the sperm epigenome and its probable role in embryonic development. These new outcomes have facilitated a broad definition of a normal epigenetic state in the male gamete while also providing insight into the potential aetiologies of various idiopathic male infertility cases [57]. Emerging studies have shown notable associations of aberrant DNA methylation in spermatozoa with idiopathic male infertility as well as increased frequency of spontaneous abortions and imprinting disorders [58]. In addition, the epigenetic errors in the process of spermatogenesis in humans have been acknowledged as causes for reduced sperm competency and reduced fertility in males. The fundamental causes of infertility in males may be seminal oxidative stress, double- and single-stranded DNA damage of both the nuclear and mitochondrial genome of sperm, sudden telomere attrition and aberrant epigenetic alterations that can not only affect a single person but also their descendants [59]. The relationships between DNA methylation levels and male fertility in humans have been investigated in several studies. The methylation load and defects of the sperm DNA have been confirmed as a cause of infertility. Emerging evidence suggest that miRNAs play an important role in male fertility. Specifically, miRNA knockout of Dicer in the sertoli cells has been shown to result in testicular dysgenesis and infertility due to alterations in sertoli cell architecture [60]. A concerted effort to identify the roles of particular miRNAs during spermatogenesis should help determine whether miRNAs can serve as important predictive or diagnostic indicators and/or a system for treating male infertility. Epimutations could lead to male infertility, as suggested in the literature. Often hypermethylation has been found to be associated with poor semen parameters or male infertility. Evaluating the implications of lifestyle habits, food intake and environmental factors (e.g., drugs and toxins) on the sperm epigenome and the subsequent effect on fertility outcomes is needed. This should be of help to better understand epigenome regulation in the male germline, and may also suggest new strategies for this line of research.

\section{2) Female infertility}

In females, epigenetic changes in the oocytes can be affected by factors such as maternal nutrition and exposure to certain toxins that have been linked with neonatal developmental and gestational defects [61]. Perturbations in epigenetic mechanisms may further elucidate the intrinsic causes of infertility or state of fertility or ovarian tumorigenesis [62]. Epigenetics in women with infertility is more complex and less explored; the factors associated with epigenetic abnormalities are diverse. These factors include ovulation problems (more common due to polycystic ovary syndrome [PCOS]), endometriosis, inflammatory disorders, age-related factors, and nutritional status [63]. PCOS is a complex multi-factorial, chronic disease state that is one of the leading causes of anovulatory infertility and subfertility. PCOS is distinguished by a range of ovarian, hormonal, and metabolic disturbances and exhibits chronic menstrual irregularities, follicular cysts on ultrasonography, hyperinsulinemia, obesity, and hyperandrogenemia. In utero hyperandrogenism exposure may perturb the epigenetic reprogramming in foetal reproductive tissue and could be a cause of post-natal PCOS. Endometriosis has not been proven to have a genetic cause, but it is worth considering that abnormal expression of candidate genes could be provoked by different epigenetic modifications including DNA methylation, heterochromatization or aberrant regulation of miRNA expression [64].

It is well established that the decline in female reproductive responses is associated with advanced maternal age and postovulatory aging of oocytes [65], which leads to compromised quality of oocytes and a lower pregnancy rate. Understanding the underlying causes of these circumstances, which may include mitochondrial dysfunctions, aneuploidy, or epigenetic changes, has recently drawn increased attention. This is an important factor in reproduction and reproductive health in order to ensure that the correct epigenetic modifications occur during oogenesis and early embryo development [66].

\section{Role in assisted reproductive technology}

Assisted reproductive techniques intended to support infertile couples in having their own children have significant risks of passing on molecular errors to the next generations [67]. Although assisted reproductive technology (ART) has become a common practice for the treatment of human infertility, the increased vulnerability of ARTconceived children to perinatal health problems is poorly understood [68]. According to the Centers for Disease Control and Prevention, "ART includes all fertility treatments in which both eggs and sperms are handled."These procedures include artificial insemination, in vitro maturation, in vitro fertilization, super-ovulation, embryo culture and transfer, and intra-cytoplasmic sperm injection [69]. ART is growing in popularity and becoming an increasingly important field. Currently, $1 \%$ to $3 \%$ of annual births occur through ART in industrialized countries and the proportion is growing [70]. These technologies are considered procedurally safe except for an increased incidence of 
premature births. In vitro culture and maturation of oocytes, superovulation, and embryo culture can stimulate epigenetic modification that might be transmitted to the next generation and expected to influence its epigenome [71]. These procedures affect the DNA methylation pattern, parental imprinting status, and expression of imprinted genes. Two important techniques employed during ART, ovarian stimulation and in vitro culture, play a crucial role in epigenetic programming events that happen naturally through gametogenesis and early embryonic development [72]. ART-related manipulations of oocytes and embryos coincide with the timing of epigenetic rewriting and sex-specific imprint acquisition. This suggests that ART can interfere with epigenetic programming events from this moment and beyond. In fact, studies show that imprinting disorders such as Beckwith-Wiedemann syndrome (BWS), Angelman syndrome and Prader-Willi syndrome are more common in children conceived by ART [72]. Several case series in children born via ART suggest that there is a three-fold to six-fold higher prevalence of ARTconceived children born with BWS than in the general population.

BWS is an overgrowth disorder where aberrant genetic and epigenetic regulation at the KCNQ1OT1 and $\mathrm{H} 19$ imprinted domains is the cause. Methylation abnormalities such as maternal LOM at KCNQ1OT1 and maternal gain of methylation at $\mathrm{H} 19$ have been identified in ART-conceived BWS children. Another common disorder seen is Angelman syndrome, which is a neurological disorder with genetic and epigenetic disturbances at the maternal LOM small nuclear ribonucleoprotein polypeptide $\mathrm{N}$-imprinted domain due to downregulation of maternal UBE3A expression that cause abnormalities [73]. The major problem identified in these ART-associated imprinting disorders is due to epimutations that are usually absent in the normal population and maternal alleles [72]. BWS also arises from imprinting defects at the SNRPN DMRs.

Observed differences in DNA methylation levels in ART and in vivo conception are not only due to the underlying infertility but also the effect of some aspect of ART procedures themselves [74]. It should be noted that ART is generally performed in individuals with infertility/ subfertility problems. As result, in most cases, successful ART produces the birth of a child that has abnormal expression due to improper imprinting in the parental lineages. This prompts the question of whether infertility/subfertility implies epigenetic reprogramming or whether the manipulation of gametes/embryos by ART leads to epigenetic alterations or whether a combination of both is involved [73]. It is possible that infertility and ART alone or in combination disrupt the complex biological pathways leading to aberrant epigenetic alterations such as the methylation status of imprinted regions and may cause imprinting disorders. However, the relatively small number of cases of ART associated with imprinting disorders makes it challenging to carry out conclusive clinical trials. Therefore, coordinated clinical and basic studies in large registries are mandatory to determine the actual impact of ART on epigenetic alterations. When the safety of human ART is considered from an epigenetic perspective, we must take into account the functional implications of epigenetic reprogramming in very early development and adult disease [68,75]. Moreover, artificial conception process not only transmits sperm nuclear DNA to the oocyte but also activation factor, centrosomes, and a host of messenger RNA and microRNAs that can influence post-fertilization activity [76]. Children born of ART need to be evaluated with long-term follow-up from childhood into adulthood to identify potential impacts of genomic imprinting in infertility and ART [77]. As nutritional and/or metabolic status influences cellular microenvironment, therefore, both these factors might also influence the epigenomic landscape of children born from assisted reproductive procedures [78].

\section{Transgenerational epigenetic inheritance}

Epigenetic information could be transmitted to the subsequent generation as genetic information is passed on, and is now discussed as transgenerational epigenetic inheritance. This event can have a broad spectrum of implications for the state of health, disease development, and more importantly, molecular adaptation and evolution. The epigenetic transmission of information can occur due to connecting links, the gametes that can pass adhered epigenetic marks from the previous generation to subsequent generations. Because the environment can induce changes in the germline epigenome that can be transmitted to subsequent progeny, therefore, might be a cause for disease aetiology observed at later stages of life [79-81]. The most common mechanism mediating transgenerational epigenetic inheritance is DNA methylation, by which the major programming occurs during early mammalian development [82]. However, ncRNAs have also been identified as a possible mechanism for regulating transgenerational transmission of information [83]. In addition, piRNAs have been noted as possible mediators of the mechanism that silences mobile genetic elements transgenerationally $[83,84]$. Evidence suggests that transgenerational epigenetic inheritance includes the transmission of epigenetic marks between generations in the absence of any environmental exposure [85], but their limits, that is, the degree to which this can occur, remain unclear [86]. Therefore, identifying the mechanisms of this mode of transmission and their impact on life is an area of epigenomics waiting to be explored.

Direct exposure generally has an effect on somatic tissues, but a transgenerational effect requires a transmission of epigenetic information with the germline. It has been demonstrated that exposure in the parental generation is remembered and transmitted to unexposed future generations through gametes as a "memory" of the environment. Environmental and metabolic conditions during gestation may shape epigenetic reprogramming and may further influ- 
ence the lifetime health of the child and the disease aetiology in offspring [87-89]. This illustrates that the intrauterine environment (nutrition, stress, and so on) has a vital effect on developmental programming, which, in turn, not only influences the germline (sperm or egg) in the foetus (F1) but also the germline of the foetus (F2) [90]. When these influences are transmitted and continue to appear across generations beyond F3, this reflects the transgenerational inheritance of epigenetics and cannot be described by direct environmental exposure anymore. Evidence from further investigation has shown that epigenetic effects could be inherited into the fourth generation. However, due to versatility of exposure and the transient nature of epigenetics, it becomes more difficult to understand the mechanisms in this complex process [91]. It has now been shown in several different laboratories and animal model systems that stress can promote the epigenetic transgenerational inheritance of disease. The account of transgenerational disease and pathology has distinct and greater frequency than direct exposure pathology, as shown in recent studies [92,93]. In this context, the epigenetic transgenerational inheritance of disease has drawn great interest and should be taken seriously in future health management and therapies. Research has shown that the exposure to environmental toxicants in the early postnatal phase can promote infertility [94]. Available molecular evidence has shown that epigenetic information carrier proteins in gametes play important roles in the transmission of phenotypes from parents to offspring [95].

Table 2. Molecular epigenetic mechanisms in regulation of spermatogenesis

\begin{tabular}{|c|c|}
\hline Spermatogenesis & Epigenetic modification \\
\hline \multirow[t]{6}{*}{ DNA methylation } & Abnormal methylation of imprinted and non-imprinted genes detected in several reproductive disorders [96] \\
\hline & Regulated chromatin and DNA methylation of adult germline stem cells for transition to gametogenesis [97] \\
\hline & $\begin{array}{l}\text { Alkylation repair homolog } 5 \text { (ALKBH5) is a m(6)A demethylase which control spermatogenesis by methylation of eukaryotic messenger } \\
\text { RNA [98] }\end{array}$ \\
\hline & Role of genomic imprinting and their perturbations in gametogenesis and early embryogenesis [99] \\
\hline & Hyper-methylated mitochondrial genome of poor-quality spermatozoa is linked with elevated tendency of apoptotic state [100] \\
\hline & Aberrant DNMT3B expression leads to bilateral spermatogenic arrest [101] \\
\hline \multirow[t]{12}{*}{ Histone modification } & $\begin{array}{l}\text { Simultaneous occurrence of trimethylated H3K79 and hyperacetylated H4 is associated with a histone-to-protamine transition protein } \\
\text { TNP1 in spermatids [104] }\end{array}$ \\
\hline & $\begin{array}{l}\text { Histone ubiquitin ligases have various regulatory functions ranging from spermatogonia differentiation and meiotic division to sper- } \\
\text { miogenesis [105] }\end{array}$ \\
\hline & Increase in histone H4 acetylation is associated with histone-to-protamine replacement in elongating spermatids [106] \\
\hline & Kdm3a lysine demethylase is required for cytoskeletal rearrangements during spermatogenesis [111] \\
\hline & Value of histone phosphorylation during spermatogenesis [112] \\
\hline & Ubiquitin-proteasome system removes and establishes key structures in the mature spermatid nucleosome [113] \\
\hline & $\begin{array}{l}\text { Dynamic modifications and expressions of histone variant } \mathrm{H} 3.1 \text { and } \mathrm{H} 3.3 \text { throughout the meiotic prophase and highly complex pattern } \\
\text { histone modifications postmeiotically in the male germ line [114] }\end{array}$ \\
\hline & JmjC domain-containing proteins have intrinsic demethylase activity toward H3K9 and are essential in spermiogenesis [115] \\
\hline & Acetylation-mediated degradation of core histones through proteasomes occurs during DNA repair and spermatogenesis [116] \\
\hline & $\begin{array}{l}\text { Dynamic acetylation and methylation modification patterns of histone } \mathrm{H} 3 \text { in certain stages of germ cell differentiation with a constant } \\
\text { presence of H3K27me3 throughout all stages [117] }\end{array}$ \\
\hline & H3K9ac in male germ cells plays a role during human spermatozoa development [118] \\
\hline & Existence of RNF8-dependent histone $\mathrm{H} 2 \mathrm{~A}$ and H2AX ubiquitination in the DNA damage response and spermatogenesis [119] \\
\hline \multirow[t]{3}{*}{ miRNA expression } & $\begin{array}{l}\text { miRNAs, small interfering RNAs, and Piwi-interacting RNAs (piRNAs) regulate gene expression at the post-transcriptional or translation } \\
\text { level in spermatogenesis [120] }\end{array}$ \\
\hline & Long noncoding RNAs are an important regulator of spermatogenesis [129] \\
\hline & $\begin{array}{l}\text { miR-449 cluster along with miR-34b/c function redundantly in male germ cell development by targeting E2F transcription factor-reti- } \\
\text { noblastoma protein (E2F-pRb) pathway [130] }\end{array}$ \\
\hline
\end{tabular}




\section{Conclusion}

Exploring and understanding the role of the epigenetic landscape in reproductive health is important. Diverse sets of consecutive epigenetic modifications form the basis of reproductive fitness (Tables $2-7)$. The key reprogramming events in reproduction ensure correct establishment and maintenance of epigenetic marks in germ cell development and early embryogenesis, while preventing the transmission of faulty information to offspring. As epigenomic landscape could be influenced by nutritional and/or metabolic factors, both these factors might also influence the cellular microenvironment during development and later stages in life. Moreover, faults generated by missing critical steps in differentiation have consequences for infertility and imprinting disorders. Furthermore, the widespread performance of ART to treat infertility demands more thorough research from the epigenetic perspective, including a comprehensive strategy and planning to address nutrition, environmental factors, and in vitro embryo production. However, the potential for far-reaching transgenerational consequences requires exploration in suitable models.

While alterations in the epigenomic landscape are required for regular growth and development, they can also be responsible for some diseases. The significance of epigenetics in maintaining normal development and biology is reflected by the observation that many health complaints build up when the wrong type of epigenetic marks are introduced or are added at the wrong time or in the wrong place. Disrupting any of the four systems that contribute to epigenetic alterations can cause abnormal activation or silencing of genes.

Table 3. Molecular epigenetic mechanisms in regulation of oogenesis

\begin{tabular}{|c|c|}
\hline Oogenesis & Epigenetic modification \\
\hline \multirow[t]{10}{*}{ DNA methylation } & Dynamic expression and variants of DMNTs are present in oogenesis [3] \\
\hline & DNMT3A/DNMT3L methylation creates imprints essential for functional imprinting in oocytes [131] \\
\hline & H3K9me3 followed by DNA methylation plays a key role in oocyte development [132] \\
\hline & $\begin{array}{l}\text { Reverse methylation patterns have been found between } \mathrm{CpG} \text { and non- } \mathrm{CpG} \text { sites in the Dnmt10 5'-upstream region and are hypometh- } \\
\text { ylated at the meiotic metaphase II stage of oogenesis and spermatogenesis [133] }\end{array}$ \\
\hline & $\begin{array}{l}\text { The histone acetyltransferases CBP (Nejire) and Chameau are required for differentiation and DNA replication programs in the stages of } \\
\text { oogenesis [134] }\end{array}$ \\
\hline & Methylated DNA is incorporated in growing oocytes by de novo DNA methylation [135] \\
\hline & $\begin{array}{l}\text { Hyperacetylation of histone } \mathrm{H} 4 \mathrm{~K} 5 \text { and phosphorylation of } \mathrm{H} 3 \text { during meiosis interferes with axial chromatid condensation, large-scale } \\
\text { chromatin remodeling and sister chromatid separation in oocytes [136] }\end{array}$ \\
\hline & DNA methylation and AKAP95 play a role in oocyte growth and fully grown prophase oocytes transfected with foreign chromatin [137] \\
\hline & Histones H2A and H4 methylation is induced by protein arginine methyltransferase Prmt5-Mep50 in late oogenesis [138] \\
\hline & $\begin{array}{l}\text { Lower level of DNA methylation at Oct4 and Sox2 promoters observed during in vitro maturation and vitrification followed as com- } \\
\text { pared to the in vivo matured oocytes [139] }\end{array}$ \\
\hline \multirow[t]{7}{*}{ Histone modification } & Bam activated H3K36 trimethylation promotes differentiation during early oogenesis [140] \\
\hline & SIRT1 plays a role in oocyte maturation in a redox state [141] \\
\hline & Dynamics of chromatin structure and function with substantial modulatory effects were revealed during oogenesis [142] \\
\hline & $\mathrm{CpG}$ islands are resistant to de novo methylation during oogenesis and associated with post-fertilization methylation maintenance [143] \\
\hline & $\begin{array}{l}\text { HDAC1 and HDAC2 play a role in acetylation of histone and non-histone proteins for regulation of transcription and apoptosis during } \\
\text { oocyte development [144] }\end{array}$ \\
\hline & $\begin{array}{l}\text { DNA demethylation and histone } \mathrm{H} 3 \text { acetylation of Lhx8-3' untranslated region is essential for primordial follicle activation during oo- } \\
\text { genesis [145] }\end{array}$ \\
\hline & MLL2, H3K4 methyltransferase is required for promoter-specific H3K4me3 during oogenesis and early development [146] \\
\hline \multirow[t]{12}{*}{ miRNA expression } & miRNA-318 maintains cell fate and promotes developmental transition in the follicular epithelium [147] \\
\hline & Endo-siRNAs are vital for meiosis I in oocyte development $[148,149]$ \\
\hline & Oocyte maturation is regulated by microRNA-378 [150] \\
\hline & Let-7 miRNA-mediated Lin28 regulates maintenance and differentiation during oogenesis [151] \\
\hline & piRNA pathway genes regulate Zfrp8/PDCD2 protein, which is essential in ovarian stem cells [152] \\
\hline & miRNAs play a role in the physiologic process of ovarian and ovulation dysfunction [153] \\
\hline & miR-124 in ovarian cells plays a role in gonad development and sex determination [154] \\
\hline & miR-989 plays a key role in border cell migration during oogenesis [155] \\
\hline & microRNA miR-7 controls the developmental switch in follicle cells by regulating zinc-finger protein Tramtrack69 [156] \\
\hline & Dicer-1 plays a critical role in oogenesis [157-159] \\
\hline & miRNA-184 has several functions in oogenesis and early embryogenesis [160] \\
\hline & miRNA has a temporal differential expression pattern during oocyte maturation [161] \\
\hline
\end{tabular}


Table 4. Molecular epigenetic mechanisms in regulation of embryogenesis

\begin{tabular}{|c|c|}
\hline Embryogenesis & Epigenetic modification \\
\hline \multirow[t]{9}{*}{ DNA methylation } & $\begin{array}{l}\text { Variable DNA methylation levels are observed at differentially methylated regions during the early stages of embryonic development } \\
\text { [162] }\end{array}$ \\
\hline & Regulation of Igf2r/Airn imprinting is allele-specific during gastrulation [163] \\
\hline & Imprinted differentially methylated domains of the germline are required for early embryo development [164] \\
\hline & De novo DNA methyltransferases and DNMT3A are activated by histone H3 during embryogenesis [165] \\
\hline & Differential methylation is selectively retained at imprinted loci during early development [166] \\
\hline & The TET family plays a dynamic role during embryogenesis and is required for the expression of NANOG in the blastocysts [167] \\
\hline & Dynamic DNA methylation occurs during preimplantation development and embryonic stages $[168,169]$ \\
\hline & $\begin{array}{l}\text { Imprint of paternally expressed gene } 1 / \text { mesoderm-specific transcript homologue is variably regulated in human preimplantation em- } \\
\text { bryos [170] }\end{array}$ \\
\hline & $\begin{array}{l}\text { JMJD3 performs active demethylation of H3K27me3 during early embryo development and is required for progression of embryos to } \\
\text { blastocysts [171] }\end{array}$ \\
\hline \multirow[t]{13}{*}{ Histone modification } & $\begin{array}{l}\text { H3K4 methylation is established at the early pronuclear stage necessary for minor zygotic gene activation and early embryonic preim- } \\
\text { plantation development [172] }\end{array}$ \\
\hline & $\begin{array}{l}\text { Various histone } \mathrm{H} 2 \mathrm{~A} \text { variants } \mathrm{H} 2 \mathrm{~A} . \mathrm{Bbd}, \mathrm{H} 2 \mathrm{~A} . \mathrm{Z} \text { and H2A.X are localized and expressed during oogenesis and preimplantation embryo } \\
\text { development [173] }\end{array}$ \\
\hline & $\begin{array}{l}\text { The oocyte H3K9/HP1 pathway recognizes and modifies the constitutive heterochromatin of sperm chromatin in preimplantation } \\
\text { embryos [174] }\end{array}$ \\
\hline & $\begin{array}{l}\text { Histone H3 lysine } 4 \text { methyltransferases (KMT2B and KMT5A) and demethylases (KDM5B and KDM1A) play a complex role during } \\
\text { mouse preimplantation embryos development [175] }\end{array}$ \\
\hline & $\begin{array}{l}\text { Hhistone modifications and chromatin remodeling controls transcription play a role in the inner cell mass and trophectoderm cell lin- } \\
\text { eages specification [176] }\end{array}$ \\
\hline & $\begin{array}{l}\text { PAD4, peptidylarginine deiminases and histone } \mathrm{H} 3 \text { citrullination are found in oocytes and preimplantation embryonic development } \\
\text { [177] }\end{array}$ \\
\hline & $\mathrm{H} 2 \mathrm{~A}$ variant $\mathrm{H} 2$ af1o specific to oocytes is essential for cell synchrony before midblastula transition in early embryos [178] \\
\hline & $\begin{array}{l}\text { Histone } \mathrm{H} 2 \mathrm{~B} \text { variant } \mathrm{TH} 2 \mathrm{~B} \text { regulates chromatin-to-nucleoprotamine transition both preceding and following transmission of } \\
\text { the male genome to the egg [179] }\end{array}$ \\
\hline & $\begin{array}{l}\text { Histone demethylases (UTX and JMJD3) particularly target the repressive H3K27me3 modification and activate bivalent genes in spe- } \\
\text { cific embryonic developmental stages [180] }\end{array}$ \\
\hline & $\begin{array}{l}\text { Bivalent histone modifications H3K4me3 and H3K27me3 are required to repress or promote differentiation during embryonic devel- } \\
\text { opment [181] }\end{array}$ \\
\hline & Sperm-specific chromatin modifications are essential for activation early in embryonic development [182] \\
\hline & Dynamic deposition of histone $\mathrm{H} 3$ variants are critical for chromatin reorganization in early embryos [183] \\
\hline & Histone H4K20me3 and HP1a are markers for cell type commitment and present in undifferentiated embryonic stem cells [184] \\
\hline \multirow[t]{13}{*}{ miRNA expression } & miRNA-21 is essential for blastocyst development in vitro by regulating transcription of PTEN, caspase-3, and Bcl-2 [185] \\
\hline & miRNA-29b regulates Dnmt3a/3b expression in early embryonic development [186] \\
\hline & Let-7a-Dicer interaction causes differential miRNA expression in dormant blastocysts and regulates the implantation potential [187] \\
\hline & The differential expression profile of miRNA in 2-cell and 4-cell embryos modulates embryonic development [188] \\
\hline & Spermatozoal RNAs impact fertilization, embryonic developmental stages and offspring phenotype [22] \\
\hline & Sperm RNAs-12 and -1 are present in one-celled embryos and the early preimplantation stages [189] \\
\hline & miRNA is expressed in blastocysts [190] \\
\hline & miRNA plays a role in translational reprogramming in oocytes and embryos [191] \\
\hline & Ion channels mediate bicarbonate-dependent activation of miRNA-125b during preimplantation embryo development [192] \\
\hline & miRNA plays a vital role in the maternal-to-embryonic transition during early development steps [193] \\
\hline & $\begin{array}{l}\text { Biogenesis expression profiling of microRNA is found diminished after fertilization and later stages of preimplantation development } \\
\text { [194] }\end{array}$ \\
\hline & Maternally expressed miRNA-206 regulates cell movement by targeting JNK signaling during gastrulation [195] \\
\hline & $\begin{array}{l}\text { Zygote-specific miRNA-135a regulates first cell cleavage in preimplantation embryo development by controlling the expression of } \\
\text { identified E3 ubiquitin ligase seven in absentia homolog 1A (Siah1a) [196] }\end{array}$ \\
\hline
\end{tabular}

Thus, an organism might be prone to epigenetic reprogramming errors during the resetting of the genome of gametes and zygotes, which differentiate to create many specific tissue types. On the other hand, the reversibility of epigenetic marks suggests the possibility that the activity of key genes and pathways can be regulated as a therapeutic approach. This suggests that the epigenome has truly ar- 
Table 5. Molecular epigenetic mechanisms in regulation of male infertility

\begin{tabular}{|c|c|}
\hline Male infertility & Epigenetic modification \\
\hline \multirow[t]{9}{*}{ DNA methylation } & Hypermethylated RHOX gene imparts infertility [197] \\
\hline & $\begin{array}{l}\text { Differential allele-specific DNA methylation at regulatory sites of piRNA genes is associated with disturbed spermatogenesis in idiopathic } \\
\text { infertility [198] }\end{array}$ \\
\hline & The hypermethylated promoter of discoidin domain receptor 1 gene causes nonobstructive azoospermia [199] \\
\hline & $\begin{array}{l}\text { Aberrant methylation of the tissue-specific differentially methylated region of the GTF2A1L promoter is correlated with male infertility } \\
\text { [200] }\end{array}$ \\
\hline & Mesoderm-specific transcript homologue DNA methylation is associated with oligozoospermia and decreased bi-testicular volume [201] \\
\hline & $\begin{array}{l}\text { Infertility is associated with the gain of methylation in spermatogenesis-related genes and loss of methylation in the inflammation/im- } \\
\text { mune response-related genes in males with subfertility [202] }\end{array}$ \\
\hline & $\begin{array}{l}\text { The genome-wide specific promoter methylation profile of cell-free seminal DNA causes defective production and maturation of sperm } \\
\text { leading to the male infertility [203] }\end{array}$ \\
\hline & Aberrant methylation imprints in sperm DNA associated with abnormal semen parameters and infertility [204] \\
\hline & Hypermethylated MTHFR promoter in sperms is linked with idiopathic male infertility [205] \\
\hline \multirow[t]{5}{*}{ Histone modification } & Chromatin remodeling and reprogramming play regulatory roles during spermatogenesis and interconnects to male infertility [108] \\
\hline & Epigenetics and subfertility are linked in males [206] \\
\hline & Epigenetics plays a role in spermatogenesis and causes reduced fertility in males [207] \\
\hline & $\begin{array}{l}\text { Altered histone retention and epigenetic modifications of developmental and imprinted gene loci are observed in the sperm of infertile } \\
\text { men [208] }\end{array}$ \\
\hline & Deficiency of Jmjd1a demethylase causes severe oligozoospermia, small testes and infertility in males [209] \\
\hline \multirow[t]{8}{*}{ miRNA expression } & miRNA-34b/c and miRNA-449a/b/c are vital for normal spermatogenesis and male fertility [210] \\
\hline & Individual differences in sperm miRNA-34 family abundance are a potential biomarker for male fertility [211] \\
\hline & miRNAs (hsa-miR-34b*, hsa-miR-34b, hsa-miR-34c-5p, hsa-miR-429, and hsa-miR-122) are a biomarker to diagnose subfertility [212] \\
\hline & miRNA expressions vary in infertile men with different histopathological patterns [213] \\
\hline & CSR-1 Argonaute functions with ALG-3/4 during spermatogenesis to amplify a small RNA signal and may promote male fertility [214] \\
\hline & Defects in ALKBH5, a RNA demethylase cause compromised spermatogenesis and male infertility [215] \\
\hline & $\begin{array}{l}\text { miRNA in asthenozoospermic and oligoasthenozoospermic males have a different expression profile than in males with normal sper- } \\
\text { matogenesis [216] }\end{array}$ \\
\hline & roRNAs in seminal plasma have an altered profile in the molecular diagnosis of male infertility [217] \\
\hline
\end{tabular}

Table 6. Molecular epigenetic mechanisms in regulation of female infertility

\begin{tabular}{|c|c|}
\hline Female infertility & Epigenetic modification \\
\hline \multirow[t]{5}{*}{ DNA methylation } & Epigenetics alterations are associated with endometriosis-related infertility [218] \\
\hline & $\begin{array}{l}\text { DNA methylation is an integral causal factor for endometriosis by disturbing the nuclear receptors genes, HOX gene clusters including } \\
\text { the GATA family [219] }\end{array}$ \\
\hline & $\begin{array}{l}\text { Endometriosis-associated infertility is observed with a decrease in expression of the HOXA10 gene due to hypermethylation in eutopic } \\
\text { mid-secretory endometrium [220] }\end{array}$ \\
\hline & $\begin{array}{l}\text { DNA hypermethylation reduces HOXA11 expression in the eutopic mid-secretory endometrium of women with endometriosis-associ- } \\
\text { ated infertility [221] }\end{array}$ \\
\hline & Involvement of DNMT3L in DNA methylation of specific patterns in endometrioma drives ovarian endometriosis [222] \\
\hline \multirow[t]{3}{*}{ Histone modification } & siRNA plays a role in reproductive failure [223] \\
\hline & $\begin{array}{l}\text { Neonatal estrogen exposure alters expression of multiple chromatin-modifying proteins and persistently alters epigenetic marks in the } \\
\text { adult uterus at the Six } 1 \text { locus leading to infertility and uterine cancer [224] }\end{array}$ \\
\hline & $\begin{array}{l}\text { Chromatin configuration and histone methylation are altered in old germinal vesicle oocytes, possibly causing infertility in advanced } \\
\text { age [225] }\end{array}$ \\
\hline \multirow[t]{9}{*}{ miRNA expression } & $\begin{array}{l}\text { miRNA-376a control primordial follicle assembly by regulating Pcna and are linked to the abnormal morphology of follicles and infertil- } \\
\text { ity [226] }\end{array}$ \\
\hline & miRNA-224 is linked to PCOS and ovulation disorder-associated infertility [92] \\
\hline & ZFP36L2, a RNA-binding protein linked with anovulation and meiotic arrest of oocytes in infertile females [227] \\
\hline & Oocyte DICER is required for follicular development and linked with female fertility in adulthood [228] \\
\hline & $\begin{array}{l}\text { The expression of the actin protein TAGLN2 is regulated by MiR-133b during oocyte growth and maturation and is a probable target for } \\
\text { infertility therapy [229] }\end{array}$ \\
\hline & $\begin{array}{l}\text { Differential miRNA expression in recurrent spontaneous abortion by targeting genes are involved in adhesion, apoptosis and angio- } \\
\text { genesis [230] }\end{array}$ \\
\hline & DNMT3A variants are associated with endometriosis and endometriosis-related infertility [231] \\
\hline & Transcription, translation and posttranslational control by miRNA in the female reproductive tract [232] \\
\hline & Differential expression of miRNA and their polymorphic target sites in endometriosis and endometriosis-related infertility $[233,234]$ \\
\hline
\end{tabular}


Table 7. Molecular epigenetic mechanisms in regulation of assisted reproductive technologies

\begin{tabular}{|c|c|}
\hline ART & Epigenetic modification \\
\hline \multirow[t]{9}{*}{ DNA methylation } & $\begin{array}{l}\text { DNA methylation reprogramming and imprinting maintenance in oogenesis and the embryo is essential for successful reproductive } \\
\text { technologies [235] }\end{array}$ \\
\hline & $\begin{array}{l}\text { DNMTs have spatial and temporal expression patterns and are disturbed in cryopreserved embryos and abnormally developing em- } \\
\text { bryos [236] }\end{array}$ \\
\hline & $\begin{array}{l}\text { Secretion of differentially expressed miRNA by blastocysts in IVF culture media depend on fertilization technique, chromosomal state, } \\
\text { and pregnancy outcome [237] }\end{array}$ \\
\hline & $\begin{array}{l}\text { Higher methylation levels of imprinted gene small nuclear ribonucleoprotein polypeptide N (SNRPN) is detected in longer duration of } \\
\text { infertility in the parents and children conceived by ICSI [238] }\end{array}$ \\
\hline & Differential expression of imprinted genes are associated with ovulation of abnormal oocytes following superovulation [239] \\
\hline & Transposable elements affect the establishment of genomic imprinting under stress conditions in the conceptus [240] \\
\hline & Genomic imprints are possible indicator of epigenetic instability in ART [73] \\
\hline & The epigenetic pattern is modulated by ART in the embryo $[71,241,242]$ \\
\hline & Aberrant methylation patterns of the IGF2/H19 locus is observed in the children conceived using assisted reproductive technology [243] \\
\hline \multirow[t]{5}{*}{ Histone modification } & ART influences the genome and epigenome of the newborn [244] \\
\hline & Altered chromatin remodeling is observed in early embryos obtained by IVF or SCNT [245] \\
\hline & Differential histone modifications are observed at multiple sites among IVF and cloned embryos during preimplantation development [246] \\
\hline & $\begin{array}{l}\text { H3K27me3 remodeling is linked with embryonic genome activation by controlling heterochromatin inherited in embryos obtained fol- } \\
\text { lowing somatic cell nuclear transfer or IVF [247] }\end{array}$ \\
\hline & Epigenetic errors in terms of genome-wide DNA methylation and chromatin organization has increased incidence in IVF than ICSI [248] \\
\hline \multirow[t]{5}{*}{ miRNA expression } & miRNA expression has a critical function IVF failure [249] \\
\hline & The presence of miRNA-320 in human follicular fluid influences embryonic development in vitro [250] \\
\hline & miRNA expression in cumulus cells is linked with the number of oocytes retrieved among females undergoing IVF [251] \\
\hline & miRNA are emerging as diagnostic markers for evaluation of implantation after ART [252] \\
\hline & The luteal phase support plays a role in expression of endometrial miRNA in controlled ovarian stimulation [253] \\
\hline
\end{tabular}

ART, assisted reproductive technology; IVF, in vitro fertilization; ICSI, intracytoplasmic sperm injection; SCNT, somatic cell nuclear transfer.

rived as a target for drug development, as pharmaceutical companies and biotech giants have programmes aimed squarely at proteins that operate in the epigenetic space. Recent technological advances are enabling research on a genome-wide scale, which is facilitating a more "systems biology"-based approach to understanding disease aetiology.

\section{Conflict of interest}

No potential conflict of interest relevant to this article was reported.

\section{Acknowledgments}

The authors are thankful to the Department of Biotechnology, Council of Scientific and Industrial Research, and Department of Science \& Technology, Government of India, New Delhi for providing financial support to the laboratory of Prof. Pradyumna Kumar Mishra.

\section{References}

1. Tollervey JR, Lunyak W. Epigenetics: judge, jury and executioner of stem cell fate. Epigenetics 2012;7:823-40.
2. Jones PA, Liang $\mathrm{G}$. Rethinking how DNA methylation patterns are maintained. Nat Rev Genet 2009;10:805-11.

3. Uysal F, Akkoyunlu G, Ozturk S. Dynamic expression of DNA methyltransferases (DNMTs) in oocytes and early embryos. Biochimie 2015;116:103-13.

4. Baylin SB, Jones PA. A decade of exploring the cancer epigenome: biological and translational implications. Nat Rev Cancer 2011;11:726-34.

5. Wu H, Zhang Y. Mechanisms and functions of Tet protein-mediated 5-methylcytosine oxidation. Genes Dev 2011;25:2436-52.

6. Bogdanovic O, Veenstra GJ. DNA methylation and methyl-CpG binding proteins: developmental requirements and function. Chromosoma 2009;118:549-65.

7. Geiman TM, Robertson KD. Chromatin remodeling, histone modifications, and DNA methylation. How does it all fit together? J Cell Biochem 2002;87:117-25.

8. Newell-Price J, Clark AJ, King P. DNA methylation and silencing of gene expression. Trends Endocrinol Metab 2000;11:142-8.

9. Wu SC, Zhang Y. Active DNA demethylation: many roads lead to Rome. Nat Rev Mol Cell Biol 2010;11:607-20.

10. Hajkova P, Jeffries SJ, Lee C, Miller N, Jackson SP, Surani MA. Genome-wide reprogramming in the mouse germ line entails the 
base excision repair pathway. Science 2010;329:78-82.

11.Chen CC, Wang KY, Shen CK. DNA 5-methylcytosine demethylation activities of the mammalian DNA methyltransferases. J Biol Chem 2013;288:9084-91.

12. Rothbart SB, Strahl BD. Interpreting the language of histone and DNA modifications. Biochim Biophys Acta 2014;1839:627-43.

13.De Gobbi M, Garrick D, Lynch M, Vernimmen D, Hughes JR, Goardon N, et al. Generation of bivalent chromatin domains during cell fate decisions. Epigenetics Chromatin 2011;4:9.

14. Vakoc CR, Sachdeva MM, Wang H, Blobel GA. Profile of histone lysine methylation across transcribed mammalian chromatin. Mol Cell Biol 2006;26:9185-95.

15. Esteller M. Non-coding RNAs in human disease. Nat Rev Genet 2011;12:861-74.

16. Knowling S, Morris KV. Non-coding RNA and antisense RNA. Nature's trash or treasure? Biochimie 2011;93:1922-7.

17. Kelly TK, Miranda TB, Liang G, Berman BP, Lin JC, Tanay A, et al. H2A.Z maintenance during mitosis reveals nucleosome shifting on mitotically silenced genes. Mol Cell 2010;39:901-11.

18. Hogg K, Western PS. Refurbishing the germline epigenome: out with the old, in with the new. Semin Cell Dev Biol 2015;45:10413.

19.Dean W. DNA methylation and demethylation: a pathway to gametogenesis and development. Mol Reprod Dev 2014;81:11325.

20.Casas E, Vavouri T. Sperm epigenomics: challenges and opportunities. Front Genet 2014;5:330.

21.Yao C, Liu Y, Sun M, Niu M, Yuan Q, Hai Y, et al. MicroRNAs and DNA methylation as epigenetic regulators of mitosis, meiosis and spermiogenesis. Reproduction 2015;150:R25-34.

22.Jodar M, Selvaraju S, Sendler E, Diamond MP, Krawetz SA; Reproductive Medicine Network. The presence, role and clinical use of spermatozoal RNAs. Hum Reprod Update 2013;19:604-24.

23. Hackett JA, Zylicz JJ, Surani MA. Parallel mechanisms of epigenetic reprogramming in the germline. Trends Genet 2012;28:16474.

24. Hackett JA, Reddington JP, Nestor CE, Dunican DS, Branco MR, Reichmann J, et al. Promoter DNA methylation couples genome-defence mechanisms to epigenetic reprogramming in the mouse germline. Development 2012;139:3623-32.

25. Yadav RP, Kotaja N. Small RNAs in spermatogenesis. Mol Cell Endocrinol 2014;382:498-508.

26.Greenlee AR, Shiao MS, Snyder E, Buaas FW, Gu T, Stearns TM, et al. Deregulated sex chromosome gene expression with male germ cell-specific loss of Dicer1. PLoS One 2012;7:e46359.

27.Wu Q, Song R, Ortogero N, Zheng H, Evanoff R, Small CL, et al. The RNase III enzyme DROSHA is essential for microRNA produc- tion and spermatogenesis. J Biol Chem 2012;287:25173-90.

28. Bui HT, Van Thuan N, Kishigami S, Wakayama S, Hikichi T, Ohta H, et al. Regulation of chromatin and chromosome morphology by histone H3 modifications in pig oocytes. Reproduction 2007; 133:371-82.

29. Tachibana M, Nozaki M, Takeda N, Shinkai Y. Functional dynamics of $\mathrm{H} 3 \mathrm{~K} 9$ methylation during meiotic prophase progression. EMBO J 2007;26:3346-59.

30.Seneda MM, Godmann M, Murphy BD, Kimmins S, Bordignon V. Developmental regulation of histone $\mathrm{H} 3$ methylation at lysine 4 in the porcine ovary. Reproduction 2008;135:829-38.

31.Monk D. Germline-derived DNA methylation and early embryo epigenetic reprogramming: the selected survival of imprints. Int J Biochem Cell Biol 2015;67:128-38.

32. Hales BF, Grenier L, Lalancette C, Robaire B. Epigenetic programming: from gametes to blastocyst. Birth Defects Res A Clin Mol Teratol 2011;91:652-65.

33. Rivera RM, Ross JW. Epigenetics in fertilization and preimplantation embryo development. Prog Biophys Mol Biol 2013;113:42332.

34. Meissner A. Epigenetic modifications in pluripotent and differentiated cells. Nat Biotechnol 2010;28:1079-88.

35.Kar S, Parbin S, Deb M, Shilpi A, Sengupta D, Rath SK, et al. Epigenetic choreography of stem cells: the DNA demethylation episode of development. Cell Mol Life Sci 2014;71:1017-32.

36.Cedar H, Bergman Y. Programming of DNA methylation patterns. Annu Rev Biochem 2012;81:97-117.

37. Yamauchi Y, Shaman JA, Ward WS. Non-genetic contributions of the sperm nucleus to embryonic development. Asian J Androl 2011;13:31-5.

38. Wossidlo M, Nakamura T, Lepikhov K, Marques CJ, Zakhartchenko V, Boiani M, et al. 5-Hydroxymethylcytosine in the mammalian zygote is linked with epigenetic reprogramming. Nat Commun 2011;2:241.

39.Tiedemann RL, Putiri EL, Lee JH, Hlady RA, Kashiwagi K, Ordog T, et al. Acute depletion redefines the division of labor among DNA methyltransferases in methylating the human genome. Cell Rep 2014;9:1554-66.

40.Senner CE. The role of DNA methylation in mammalian development. Reprod Biomed Online 2011;22:529-35.

41. Messerschmidt DM, Knowles BB, Solter D. DNA methylation dynamics during epigenetic reprogramming in the germline and preimplantation embryos. Genes Dev 2014;28:812-28.

42.Seisenberger S, Peat JR, Hore TA, Santos F, Dean W, Reik W. Reprogramming DNA methylation in the mammalian life cycle: building and breaking epigenetic barriers. Philos Trans R Soc Lond B Biol Sci 2013;368:20110330. 
43. Hajkova P. Epigenetic reprogramming in the germline: towards the ground state of the epigenome. Philos Trans R Soc Lond B Biol Sci 2011;366:2266-73.

44.Seisenberger S, Peat JR, Reik W. Conceptual links between DNA methylation reprogramming in the early embryo and primordial germ cells. Curr Opin Cell Biol 2013;25:281-8.

45. Hemberger M, Dean W, Reik W. Epigenetic dynamics of stem cells and cell lineage commitment: digging Waddington's canal. Nat Rev Mol Cell Biol 2009;10:526-37.

46.Cantone I, Fisher AG. Epigenetic programming and reprogramming during development. Nat Struct Mol Biol 2013;20:282-9.

47.Burton A, Torres-Padilla ME. Chromatin dynamics in the regulation of cell fate allocation during early embryogenesis. Nat Rev Mol Cell Biol 2014;15:723-34.

48.Burton A, Torres-Padilla ME. Epigenetic reprogramming and development: a unique heterochromatin organization in the preimplantation mouse embryo. Brief Funct Genomics 2010;9:44454.

49.Deb M, Kar S, Sengupta D, Shilpi A, Parbin S, Rath SK, et al. Chromatin dynamics: $\mathrm{H} 3 \mathrm{~K} 4$ methylation and $\mathrm{H} 3$ variant replacement during development and in cancer. Cell Mol Life Sci 2014;71: 3439-63.

50.Fisher CL, Fisher AG. Chromatin states in pluripotent, differentiated, and reprogrammed cells. Curr Opin Genet Dev 2011;21: 140-6.

51.Santenard A, Ziegler-Birling C, Koch M, Tora L, Bannister AJ, Torres-Padilla ME. Heterochromatin formation in the mouse embryo requires critical residues of the histone variant H3.3. Nat Cell Biol 2010;12:853-62.

52.Gu SG, Pak J, Guang S, Maniar JM, Kennedy S, Fire A. Amplification of siRNA in Caenorhabditis elegans generates a transgenerational sequence-targeted histone $\mathrm{H} 3$ lysine 9 methylation footprint. Nat Genet 2012;44:157-64.

53.Sendler E, Johnson GD, Mao S, Goodrich RJ, Diamond MP, Hauser $\mathrm{R}$, et al. Stability, delivery and functions of human sperm RNAs at fertilization. Nucleic Acids Res 2013;41:4104-17.

54.Sanli I, Feil R. Chromatin mechanisms in the developmental control of imprinted gene expression. Int J Biochem Cell Biol 2015;67:139-47.

55.MacDonald WA, Mann MR. Epigenetic regulation of genomic imprinting from germ line to preimplantation. Mol Reprod Dev 2014;81:126-40.

56.Kaneda M, Okano M, Hata K, Sado T, Tsujimoto N, Li E, et al. Essential role for de novo DNA methyltransferase Dnmt3a in paternal and maternal imprinting. Nature 2004;429:900-3.

57.Jenkins TG, Carrell DT. The sperm epigenome and potential implications for the developing embryo. Reproduction 2012;143:
727-34.

58. Klaver R, Gromoll J. Bringing epigenetics into the diagnostics of the andrology laboratory: challenges and perspectives. Asian J Androl 2014;16:669-74.

59. Mishra PK, Bunkar N, Raghuram GV, Khare NK, Pathak N, Bhargava A. Epigenetic dimension of oxygen radical injury in spermatogonial epithelial cells. Reprod Toxicol 2015;52:40-56.

60.Papaioannou MD, Pitetti JL, Ro S, Park C, Aubry F, Schaad O, et al. Sertoli cell Dicer is essential for spermatogenesis in mice. Dev Biol 2009;326:250-9.

61.Stringer JM, Barrand S, Western P. Fine-tuning evolution: germline epigenetics and inheritance. Reproduction 2013;146:R3748.

62. Raghuram GV, Mishra PK. Stress induced premature senescence: a new culprit in ovarian tumorigenesis? Indian J Med Res 2014; 140 Suppl:S120-9.

63. Han SJ, O'Malley BW. The dynamics of nuclear receptors and nuclear receptor coregulators in the pathogenesis of endometriosis. Hum Reprod Update 2014;20:467-84.

64.Baranov VS, Ivaschenko TE, Liehr T, Yarmolinskaya MI. Systems genetics view of endometriosis: a common complex disorder. Eur J Obstet Gynecol Reprod Biol 2015;185:59-65.

65.Liang X, Ma J, Schatten H, Sun Q. Epigenetic changes associated with oocyte aging. Sci China Life Sci 2012;55:670-6.

66.Ge ZJ, Schatten H, Zhang CL, Sun QY. Oocyte ageing and epigenetics. Reproduction 2015;149:R103-14.

67.Tahmasbpour E, Balasubramanian D, Agarwal A. A multi-faceted approach to understanding male infertility: gene mutations, molecular defects and assisted reproductive techniques (ART). J Assist Reprod Genet 2014;31:1115-37.

68.El Hajj N, Haaf T. Epigenetic disturbances in in vitro cultured gametes and embryos: implications for human assisted reproduction. Fertil Steril 2013;99:632-41.

69. Kohda T. Effects of embryonic manipulation and epigenetics. J Hum Genet 2013;58:416-20.

70. Eroglu A, Layman LC. Role of ART in imprinting disorders. Semin Reprod Med 2012;30:92-104.

71.van Montfoort AP, Hanssen LL, de Sutter P, Viville S, Geraedts JP, de Boer P. Assisted reproduction treatment and epigenetic inheritance. Hum Reprod Update 2012;18:171-97.

72. de Waal E, McCarrey JR. Effects of exogenous endocrine stimulation on epigenetic programming of the female germline genome. Anim Reprod 2010;7:154-64.

73.Denomme MM, Mann MR. Genomic imprints as a model for the analysis of epigenetic stability during assisted reproductive technologies. Reproduction 2012;144:393-409.

74.Song S, Ghosh J, Mainigi M, Turan N, Weinerman R, Truongcao M, 
et al. DNA methylation differences between in vitro- and in vivoconceived children are associated with ART procedures rather than infertility. Clin Epigenetics 2015;7:41.

75.Lucas E. Epigenetic effects on the embryo as a result of periconceptional environment and assisted reproduction technology. Reprod Biomed Online 2013;27:477-85.

76. Kumar M, Kumar K, Jain S, Hassan T, Dada R. Novel insights into the genetic and epigenetic paternal contribution to the human embryo. Clinics (Sao Paulo) 2013;68 Suppl 1:5-14.

77.Kurinczuk JJ, Bhattacharya S. Rare chromosomal, genetic, and epigenetic-related risks associated with infertility treatment. Semin Fetal Neonatal Med 2014;19:250-3.

78.McGraw S, Oakes CC, Martel J, Cirio MC, de Zeeuw P, Mak W, et al. Loss of DNMT1o disrupts imprinted $X$ chromosome inactivation and accentuates placental defects in females. PLoS Genet 2013;9:e1003873.

79.Skinner MK. Role of epigenetics in developmental biology and transgenerational inheritance. Birth Defects Res C Embryo Today 2011;93:51-5.

80.Nilsson E, Larsen G, Manikkam M, Guerrero-Bosagna C, Savenkova MI, Skinner MK. Environmentally induced epigenetic transgenerational inheritance of ovarian disease. PLoS One 2012;7: e36129.

81.Fernandez AF, Torano EG, Urdinguio RG, Lana AG, Fernandez IA, Fraga MF. The epigenetic basis of adaptation and responses to environmental change: perspective on human reproduction. Adv Exp Med Biol 2014;753:97-117.

82.Lange UC, Schneider R. What an epigenome remembers. Bioessays 2010;32:659-68.

83.Kuramochi-Miyagawa S, Watanabe T, Gotoh K, Totoki Y, Toyoda A, Ikawa $\mathrm{M}$, et al. DNA methylation of retrotransposon genes is regulated by Piwi family members MILI and MIWI2 in murine fetal testes. Genes Dev 2008;22:908-17.

84.Daxinger L, Whitelaw E. Understanding transgenerational epigenetic inheritance via the gametes in mammals. Nat Rev Genet 2012;13:153-62.

85.Skinner MK, Manikkam M, Guerrero-Bosagna C. Epigenetic transgenerational actions of environmental factors in disease etiology. Trends Endocrinol Metab 2010;21:214-22.

86. Heard E, Martienssen RA. Transgenerational epigenetic inheritance: myths and mechanisms. Cell 2014;157:95-109.

87.Mishra PK. A pragmatic \& translational approach of human biomonitoring to methyl isocyanate exposure in Bhopal. Indian J Med Res 2012;135:479-84.

88. Mishra PK, Raghuram GV, Bunkar N, Bhargava A, Khare NK. Molecular bio-dosimetry for carcinogenic risk assessment in survivors of Bhopal gas tragedy. Int J Occup Med Environ Health
2015;28:921-39.

89.Bunkar N, Bhargava A, Khare NK, Mishra PK. Mitochondrial anomalies: driver to age associated degenerative human ailments. Front Biosci (Landmark Ed) 2016;21:769-93.

90.Mishra PK, Lohiya NK. Prioritizing reproductive health: can it be the real game changer for India? J Reprod Health Med 2016;2:13.

91.Skinner MK. Environmental epigenetic transgenerational inheritance and somatic epigenetic mitotic stability. Epigenetics 2011;6:838-42.

92. Yao Y, Robinson AM, Zucchi FC, Robbins JC, Babenko O, Kovalchuk $\mathrm{O}$, et al. Ancestral exposure to stress epigenetically programs preterm birth risk and adverse maternal and newborn outcomes. BMC Med 2014;12:121.

93.Skinner MK, Manikkam M, Tracey R, Guerrero-Bosagna C, Haque $M$, Nilsson EE. Ancestral dichlorodiphenyltrichloroethane (DDT) exposure promotes epigenetic transgenerational inheritance of obesity. BMC Med 2013;11:228.

94.Guerrero-Bosagna C, Skinner MK. Environmentally induced epigenetic transgenerational inheritance of male infertility. Curr Opin Genet Dev 2014;26:79-88.

95. Wei Y, Schatten H, Sun QY. Environmental epigenetic inheritance through gametes and implications for human reproduction. Hum Reprod Update 2015;21:194-208.

96.Calicchio R, Doridot L, Miralles F, Mehats C, Vaiman D. DNA methylation, an epigenetic mode of gene expression regulation in reproductive science. Curr Pharm Des 2014;20:1726-50.

97.Hammoud SS, Low DH, Yi C, Carrell DT, Guccione E, Cairns BR. Chromatin and transcription transitions of mammalian adult germline stem cells and spermatogenesis. Cell Stem Cell 2014; 15:239-53.

98.Liu J, Jia G. Methylation modifications in eukaryotic messenger RNA. J Genet Genomics 2014;41:21-33.

99.Denomme MM, Mann MR. Maternal control of genomic imprint maintenance. Reprod Biomed Online 2013;27:629-36.

100. Barzideh J, Scott RJ, Aitken RJ. Analysis of the global methylation status of human spermatozoa and its association with the tendency of these cells to enter apoptosis. Andrologia 2013;45:4249.

101. Adiga SK, Ehmcke J, Schlatt S, Kliesch S, Westernstroer B, Luetjens CM, et al. Reduced expression of DNMT3B in the germ cells of patients with bilateral spermatogenic arrest does not lead to changes in the global methylation status. Mol Hum Reprod 2011;17:545-9.

102. Zhang A, Skaar DA, Li Y, Huang D, Price TM, Murphy SK, et al. Novel retrotransposed imprinted locus identified at human 6p25. Nucleic Acids Res 2011;39:5388-400. 
103. Navarro-Costa $P$, Nogueira $P$, Carvalho $M$, Leal F, Cordeiro I, Calhaz-Jorge $C$, et al. Incorrect DNA methylation of the DAZL promoter CpG island associates with defective human sperm. Hum Reprod 2010;25:2647-54.

104. Dottermusch-Heidel C, Klaus ES, Gonzalez NH, Bhushan S, Meinhardt A, Bergmann M, et al. H3K79 methylation directly precedes the histone-to-protamine transition in mammalian spermatids and is sensitive to bacterial infections. Andrology 2014;2: 655-65.

105. Sheng K, Liang X, Huang S, Xu W. The role of histone ubiquitination during spermatogenesis. Biomed Res Int 2014;2014:870695.

106. Shirakata Y, Hiradate Y, Inoue H, Sato E, Tanemura K. Histone h4 modification during mouse spermatogenesis. J Reprod Dev 2014;60:383-7.

107. Rathke C, Baarends WM, Awe S, Renkawitz-Pohl R. Chromatin dynamics during spermiogenesis. Biochim Biophys Acta 2014; 1839:155-68.

108. Hisano M, Erkek S, Dessus-Babus S, Ramos L, Stadler MB, Peters $\mathrm{AH}$. Genome-wide chromatin analysis in mature mouse and human spermatozoa. Nat Protoc 2013;8:2449-70.

109. Samson M, Jow MM, Wong CC, Fitzpatrick C, Aslanian A, Saucedo l, et al. The specification and global reprogramming of histone epigenetic marks during gamete formation and early embryo development in C. elegans. PLoS Genet 2014;10:e1004588.

110. Zhuang T, Hess RA, Kolla V, Higashi M, Raabe TD, Brodeur GM. CHD5 is required for spermiogenesis and chromatin condensation. Mech Dev 2014;131:35-46.

111. Kasioulis I, Syred HM, Tate P, Finch A, Shaw J, Seawright A, et al. $\mathrm{Kdm} 3 \mathrm{a}$ lysine demethylase is an Hsp90 client required for cytoskeletal rearrangements during spermatogenesis. Mol Biol Cell 2014;25:1216-33.

112. Zhang Z, Kang X, Mu S. Histone phosphorylation and spermatogenesis. Yi Chuan 2014;36:220-7.

113. Bose R, Manku G, Culty M, Wing SS. Ubiquitin-proteasome system in spermatogenesis. Adv Exp Med Biol 2014;759:181-213.

114. Hennig W, Weyrich A. Histone modifications in the male germ line of Drosophila. BMC Dev Biol 2013;13:7.

115. Kuroki S, Akiyoshi M, Tokura M, Miyachi H, Nakai Y, Kimura H, et al. JMJD1C, a JmjC domain-containing protein, is required for long-term maintenance of male germ cells in mice. Biol Reprod 2013;89:93.

116. Qian MX, Pang Y, Liu CH, Haratake K, Du BY, Ji DY, et al. Acetylation-mediated proteasomal degradation of core histones during DNA repair and spermatogenesis. Cell 2013;153:1012-24.

117. Song N, Liu J, An S, Nishino T, Hishikawa Y, Koji T. Immunohistochemical analysis of histone $\mathrm{H} 3$ modifications in germ cells during mouse spermatogenesis. Acta Histochem Cytochem 2011;
44:183-90

118. Steilmann C, Paradowska A, Bartkuhn M, Vieweg M, Schuppe HC, Bergmann $\mathrm{M}$, et al. Presence of histone $\mathrm{H} 3$ acetylated at lysine 9 in male germ cells and its distribution pattern in the genome of human spermatozoa. Reprod Fertil Dev 2011;23:997-1011.

119. Ma T, Keller JA, Yu X. RNF8-dependent histone ubiquitination during DNA damage response and spermatogenesis. Acta Biochim Biophys Sin (Shanghai) 2011;43:339-45.

120. Bak CW, Yoon TK, Choi Y. Functions of PIWI proteins in spermatogenesis. Clin Exp Reprod Med 2011;38:61-7.

121. Taguchi YH. Apparent microRNA-Target-specific histone modification in mammalian spermatogenesis. Evol Bioinform Online 2015;11(Suppl 1):13-26.

122. Salas-Huetos A, Blanco J, Vidal F, Godo A, Grossmann M, Pons $M C$, et al. Spermatozoa from patients with seminal alterations exhibit a differential micro-ribonucleic acid profile. Fertil Steril 2015;104:591-601.

123. de Mateo S, Sassone-Corsi P. Regulation of spermatogenesis by small non-coding RNAs: role of the germ granule. Semin Cell Dev Biol 2014;29:84-92.

124. Kotaja N. MicroRNAs and spermatogenesis. Fertil Steril 2014;101: 1552-62.

125. van den Driesche S, Sharpe RM, Saunders PT, Mitchell RT. Regulation of the germ stem cell niche as the foundation for adult spermatogenesis: a role for miRNAs? Semin Cell Dev Biol 2014; 29:76-83.

126. Salas-Huetos A, Blanco J, Vidal F, Mercader JM, Garrido N, Anton E. New insights into the expression profile and function of microribonucleic acid in human spermatozoa. Fertil Steril 2014;102: 213-22.e4.

127. Yang $\mathrm{Q}$, Hua J, Wang L, Xu B, Zhang $\mathrm{H}$, Ye N, et al. MicroRNA and piRNA profiles in normal human testis detected by next generation sequencing. PLoS One 2013;8:e66809.

128. Huszar JM, Payne CJ. MicroRNA 146 (Mir146) modulates spermatogonial differentiation by retinoic acid in mice. Biol Reprod 2013;88:15.

129. Mclver SC, Roman SD, Nixon B, McLaughlin EA. miRNA and mammalian male germ cells. Hum Reprod Update 2012;18:4459.

130. Bao J, Li D, Wang L, Wu J, Hu Y, Wang Z, et al. MicroRNA-449 and microRNA-34b/c function redundantly in murine testes by targeting E2F transcription factor-retinoblastoma protein (E2FpRb) pathway. J Biol Chem 2012;287:21686-98.

131. Hara S, Takano T, Fujikawa T, Yamada M, Wakai T, Kono T, et al. Forced expression of DNA methyltransferases during oocyte growth accelerates the establishment of methylation imprints but not functional genomic imprinting. Hum Mol Genet 2014; 
23:3853-64.

132. Russo V, Bernabo N, Di Giacinto O, Martelli A, Mauro A, Berardinelli $\mathrm{P}$, et al. H3K9 trimethylation precedes DNA methylation during sheep oogenesis: HDAC1, SUV39H1, G9a, HP1, and Dnmts are involved in these epigenetic events. J Histochem Cytochem 2013;61:75-89.

133. Ko YG, Yun J, Park HJ, Tanaka S, Shiota K, Cho JH. Dynamic methylation pattern of the ethyltransferase1o (Dnmt1o) 5'-flanking region during mouse oogenesis and spermatogenesis. Mol Reprod Dev 2013;80:212-22.

134. McConnell KH, Dixon M, Calvi BR. The histone acetyltransferases CBP and Chameau integrate developmental and DNA replication programs in Drosophila ovarian follicle cells. Development 2012;139:3880-90.

135. Tomizawa S, Nowacka-Woszuk J, Kelsey G. DNA methylation establishment during oocyte growth: mechanisms and significance. Int J Dev Biol 2012;56:867-75.

136. Yang F, Baumann C, Viveiros MM, De La Fuente R. Histone hyperacetylation during meiosis interferes with large-scale chromatin remodeling, axial chromatid condensation and sister chromatid separation in the mammalian oocyte. Int J Dev Biol 2012;56:88999.

137. Hoffmann S, Tomasik G, Polanski Z. DNA methylation, histone modifications and behaviour of AKAP95 during mouse oocyte growth and upon nuclear transfer of foreign chromatin into fully grown prophase oocytes. Folia Biol (Krakow) 2012;60:163-70.

138. Wilczek C, Chitta R, Woo E, Shabanowitz J, Chait BT, Hunt DF, et al. Protein arginine methyltransferase Prmt5-Mep50 methylates histones $\mathrm{H} 2 \mathrm{~A}$ and $\mathrm{H} 4$ and the histone chaperone nucleoplasmin in Xenopus laevis eggs. J Biol Chem 2011;286:42221-31.

139. Milroy C, Liu L, Hammoud S, Hammoud A, Peterson CM, Carrell DT. Differential methylation of pluripotency gene promoters in in vitro matured and vitrified, in vivo-matured mouse oocytes. Fertil Steril 2011;95:2094-9.

140. Mukai M, Hira S, Nakamura K, Nakamura S, Kimura H, Sato M, et al. H3K36 trimethylation-mediated epigenetic regulation is activated by bam and promotes germ cell differentiation during early oogenesis in drosophila. Biol Open 2015;4:119-24.

141. Di Emidio G, Falone S, Vitti M, D’Alessandro AM, Vento M, Di Pietro $C$, et al. SIRT1 signalling protects mouse oocytes against oxidative stress and is deregulated during aging. Hum Reprod 2014;29:2006-17.

142. Luciano AM, Franciosi F, Dieci C, Lodde V. Changes in large-scale chromatin structure and function during oogenesis: a journey in company with follicular cells. Anim Reprod Sci 2014;149:3-10.

143. Saadeh H, Schulz R. Protection of CpG islands against de novo DNA methylation during oogenesis is associated with the recog- nition site of E2f1 and E2f2. Epigenetics Chromatin 2014;7:26.

144. Ma P, Pan H, Montgomery RL, Olson EN, Schultz RM. Compensatory functions of histone deacetylase 1 (HDAC1) and HDAC2 regulate transcription and apoptosis during mouse oocyte development. Proc Natl Acad Sci U S A 2012;109:E481-9.

145. Zhang L, Pan B, Chen B, Zhang XF, Liang GJ, Feng YN, et al. Expression and epigenetic dynamics of transcription regulator Lhx8 during mouse oogenesis. Gene 2012;506:1-9.

146. Andreu-Vieyra CV, Chen R, Agno JE, Glaser S, Anastassiadis K, Stewart AF, et al. MLL2 is required in oocytes for bulk histone 3 lysine 4 trimethylation and transcriptional silencing. PLoS Biol 2010;8.

147. Ge W, Deng Q, Guo T, Hong X, Kugler JM, Yang X, et al. Regulation of pattern formation and gene amplification during Drosophila oogenesis by the miR-318 microRNA. Genetics 2015;200: 255-65.

148. Stein P, Rozhkov NV, Li F, Cardenas FL, Davydenko O, Vandivier $\mathrm{LE}$, et al. Essential role for endogenous siRNAs during meiosis in mouse oocytes. PLoS Genet 2015;11:e1005013.

149. Suh N, Blelloch R. Small RNAs in early mammalian development: from gametes to gastrulation. Development 2011;138:1653-61.

150. Pan B, Toms D, Shen W, Li J. MicroRNA-378 regulates oocyte maturation via the suppression of aromatase in porcine cumulus cells. Am J Physiol Endocrinol Metab 2015;308:E525-34.

151. Stratoulias V, Heino TI, Michon F. Lin-28 regulates oogenesis and muscle formation in Drosophila melanogaster. PLoS One 2014; 9:e101141.

152. Minakhina S, Changela N, Steward R. Zfrp8/PDCD2 is required in ovarian stem cells and interacts with the piRNA pathway machinery. Development 2014;141:259-68.

153. Imbar T, Eisenberg I. Regulatory role of microRNAs in ovarian function. Fertil Steril 2014;101:1524-30.

154. Real FM, Sekido R, Lupianez DG, Lovell-Badge R, Jimenez R, Burgos M. A microRNA (mmu-miR-124) prevents Sox9 expression in developing mouse ovarian cells. Biol Reprod 2013;89:78.

155. Kugler JM, Verma P, Chen YW, Weng R, Cohen SM. miR-989 is required for border cell migration in the Drosophila ovary. PLoS One 2013;8:e67075.

156. Huang YC, Smith L, Poulton J, Deng WM. The microRNA miR-7 regulates Tramtrack69 in a developmental switch in Drosophila follicle cells. Development 2013;140:897-905.

157. Tanaka ED, Piulachs MD. Dicer-1 is a key enzyme in the regulation of oogenesis in panoistic ovaries. Biol Cell 2012;104:452-61.

158. Beshore EL, McEwen TJ, Jud MC, Marshall JK, Schisa JA, Bennett $\mathrm{KL}$. C. elegans Dicer interacts with the P-granule component GLH-1 and both regulate germline RNPs. Dev Biol 2011;350:37081. 
159. Liu HC, Tang Y, He Z, Rosenwaks Z. Dicer is a key player in oocyte maturation. J Assist Reprod Genet 2010;27:571-80.

160. lovino N, Pane A, Gaul U. miR-184 has multiple roles in Drosophila female germline development. Dev Cell 2009;17:123-33.

161. Tesfaye D, Worku D, Rings F, Phatsara C, Tholen E, Schellander K, et al. Identification and expression profiling of microRNAs during bovine oocyte maturation using heterologous approach. Mol Reprod Dev 2009;76:665-77.

162. O'Doherty AM, Magee DA, O'Shea LC, Forde N, Beltman ME, Mamo $S$, et al. DNA methylation dynamics at imprinted genes during bovine pre-implantation embryo development. BMC Dev Biol 2015;15:13.

163. Marcho C, Bevilacqua A, Tremblay KD, Mager J. Tissue-specific regulation of Igf2r/Airn imprinting during gastrulation. Epigenetics Chromatin 2015;8:10.

164. McGraw S, Zhang JX, Farag M, Chan D, Caron M, Konermann C, et al. Transient DNMT1 suppression reveals hidden heritable marks in the genome. Nucleic Acids Res 2015;43:1485-97.

165. Guo X, Wang L, Li J, Ding Z, Xiao J, Yin X, et al. Structural insight into autoinhibition and histone $\mathrm{H} 3$-induced activation of DNMT3A. Nature 2015;517:640-4.

166. Kelsey G, Feil R. New insights into establishment and maintenance of DNA methylation imprints in mammals. Philos Trans $R$ Soc Lond B Biol Sci 2013;368:20110336.

167. Lee K, Hamm J, Whitworth K, Spate L, Park KW, Murphy CN, et al. Dynamics of TET family expression in porcine preimplantation embryos is related to zygotic genome activation and required for the maintenance of NANOG. Dev Biol 2014;386:86-95.

168. Tanaka S, Nakanishi MO, Shiota K. DNA methylation and its role in the trophoblast cell lineage. Int J Dev Biol 2014;58:231-8.

169. Smith ZD, Chan MM, Humm KC, Karnik R, Mekhoubad S, Regev A, et al. DNA methylation dynamics of the human preimplantation embryo. Nature 2014;511:611-5.

170. Huntriss JD, Hemmings KE, Hinkins M, Rutherford AJ, Sturmey RG, Elder K, et al. Variable imprinting of the MEST gene in human preimplantation embryos. Eur J Hum Genet 2013;21:40-7.

171. Canovas S, Cibelli JB, Ross PJ. Jumonji domain-containing protein 3 regulates histone 3 lysine 27 methylation during bovine preimplantation development. Proc Natl Acad Sci U S A 2012; 109:2400-5.

172. Aoshima K, Inoue E, Sawa H, Okada Y. Paternal H3K4 methylation is required for minor zygotic gene activation and early mouse embryonic development. EMBO Rep 2015;16:803-12.

173. Wu BJ, Dong FL, Ma XS, Wang XG, Lin F, Liu HL. Localization and expression of histone $\mathrm{H} 2 \mathrm{~A}$ variants during mouse oogenesis and preimplantation embryo development. Genet Mol Res 2014;13: 5929-39.
174. van de Werken C, van der Heijden GW, Eleveld C, Teeuwssen M, Albert M, Baarends WM, et al. Paternal heterochromatin formation in human embryos is H3K9/HP1 directed and primed by sperm-derived histone modifications. Nat Commun 2014;5: 5868.

175. Shao GB, Chen JC, Zhang LP, Huang P, Lu HY, Jin J, et al. Dynamic patterns of histone $\mathrm{H} 3$ lysine 4 methyltransferases and demethylases during mouse preimplantation development. In Vitro Cell Dev Biol Anim 2014;50:603-13.

176. Paul S, Knott JG. Epigenetic control of cell fate in mouse blastocysts: the role of covalent histone modifications and chromatin remodeling. Mol Reprod Dev 2014;81:171-82.

177. Brahmajosyula M, Miyake M. Localization and expression of peptidylarginine deiminase 4 (PAD4) in mammalian oocytes and preimplantation embryos. Zygote 2013;21:314-24.

178. Yue HM, Li Z, Wu N, Liu Z, Wang Y, Gui JF. Oocyte-specific H2A variant $\mathrm{H} 2 \mathrm{af1}$ o is required for cell synchrony before midblastula transition in early zebrafish embryos. Biol Reprod 2013;89:82.

179. Montellier E, Boussouar F, Rousseaux S, Zhang K, Buchou T, Fenaille $F$, et al. Chromatin-to-nucleoprotamine transition is controlled by the histone H2B variant TH2B. Genes Dev 2013;27: 1680-92.

180. Welstead GG, Creyghton MP, Bilodeau S, Cheng AW, Markoulaki S, Young RA, et al. X-linked H3K27me3 demethylase Utx is required for embryonic development in a sex-specific manner. Proc Natl Acad Sci U S A 2012;109:13004-9.

181. Vastenhouw NL, Schier AF. Bivalent histone modifications in early embryogenesis. Curr Opin Cell Biol 2012;24:374-86.

182. Jenkins TG, Carrell DT. The paternal epigenome and embryogenesis: poising mechanisms for development. Asian J Androl 2011;13:76-80.

183. Akiyama T, Suzuki O, Matsuda J, Aoki F. Dynamic replacement of histone $\mathrm{H} 3$ variants reprograms epigenetic marks in early mouse embryos. PLoS Genet 2011;7:e1002279.

184. Wongtawan T, Taylor JE, Lawson KA, Wilmut I, Pennings S. Histone H4K20me3 and HP1a are late heterochromatin markers in development, but present in undifferentiated embryonic stem cells. J Cell Sci 2011;124:1878-90.

185. Zhang C, Shi YR, Liu XR, Cao YC, Zhen D, Jia ZY, et al. The antiapoptotic role of berberine in preimplantation embryo in vitro development through regulation of miRNA-21. PLoS One 2015; 10:e0129527.

186. Zhang J, Wang Y, Liu X, Jiang S, Zhao C, Shen R, et al. Expression and potential role of microRNA-29b in mouse early embryo development. Cell Physiol Biochem 2015;35:1178-87.

187. Cheong AW, Pang RT, Liu WM, Kottawatta KS, Lee KF, Yeung WS. MicroRNA Let-7a and dicer are important in the activation and 
implantation of delayed implanting mouse embryos. Hum Reprod 2014;29:750-62.

188. Wang P, Cui J, Zhao C, Zhou L, Guo X, Shen R, et al. Differential expression of microRNAs in 2-cell and 4-cell mouse embryos. Zygote 2014;22:455-61.

189. Kawano M, Kawaji H, Grandjean V, Kiani J, Rassoulzadegan M. Novel small noncoding RNAs in mouse spermatozoa, zygotes and early embryos. PLoS One 2012;7:e44542.

190. Rosenbluth EM, Shelton DN, Sparks AE, Devor E, Christenson L, Van Voorhis BJ. MicroRNA expression in the human blastocyst. Fertil Steril 2013;99:855-61.e3.

191. Hossain MM, Salilew-Wondim D, Schellander K, Tesfaye D. The role of microRNAs in mammalian oocytes and embryos. Anim Reprod Sci 2012;134:36-44.

192. Lu YC, Chen H, Fok KL, Tsang LL, Yu MK, Zhang XH, et al. CFTR mediates bicarbonate-dependent activation of miR-125b in preimplantation embryo development. Cell Res 2012;22:145366.

193. Mondou E, Dufort I, Gohin M, Fournier E, Sirard MA. Analysis of microRNAs and their precursors in bovine early embryonic development. Mol Hum Reprod 2012;18:425-34.

194. Garcia-Lopez J, del Mazo J. Expression dynamics of microRNA biogenesis during preimplantation mouse development. Biochim Biophys Acta 2012;1819:847-54.

195. Liu X, Ning G, Meng A, Wang Q. MicroRNA-206 regulates cell movements during zebrafish gastrulation by targeting prickle1a and regulating c-Jun $\mathrm{N}$-terminal kinase 2 phosphorylation. Mol Cell Biol 2012;32:2934-42.

196. Pang RT, Liu WM, Leung CO, Ye TM, Kwan PC, Lee KF, et al. miR$135 \mathrm{~A}$ regulates preimplantation embryo development through down-regulation of E3 Ubiquitin Ligase Seven In Absentia Homolog 1A (SIAH1A) expression. PLoS One 2011;6:e27878.

197. Richardson ME, Bleiziffer A, Tuttelmann F, Gromoll J, Wilkinson MF. Epigenetic regulation of the RHOX homeobox gene cluster and its association with human male infertility. Hum Mol Genet 2014;23:12-23.

198. Friemel C, Ammerpohl O, Gutwein J, Schmutzler AG, Caliebe A, Kautza $M$, et al. Array-based DNA methylation profiling in male infertility reveals allele-specific DNA methylation in PIWIL1 and PIWIL2. Fertil Steril 2014;101:1097-103.e1.

199. Ramasamy R, Ridgeway A, Lipshultz LI, Lamb DJ. Integrative DNA methylation and gene expression analysis identifies discoidin domain receptor 1 association with idiopathic nonobstructive azoospermia. Fertil Steril 2014;102:968-73.e3.

200. Sugimoto K, Koh E, lijima M, Taya M, Maeda Y, Namiki M. Aberrant methylation of the TDMR of the GTF2A1L promoter does not affect fertilisation rates via TESE in patients with hyposper- matogenesis. Asian J Androl 2013;15:634-9.

201. Klaver R, Tuttelmann F, Bleiziffer A, Haaf T, Kliesch S, Gromoll J. DNA methylation in spermatozoa as a prospective marker in andrology. Andrology 2013;1:731-40.

202. Schutte B, El Hajj N, Kuhtz J, Nanda I, Gromoll J, Hahn T, et al. Broad DNA methylation changes of spermatogenesis, inflammation and immune response-related genes in a subgroup of sperm samples for assisted reproduction. Andrology 2013;1:8229.

203. Wu C, Ding X, Li H, Zhu C, Xiong C. Genome-wide promoter methylation profile of human testis and epididymis: identified from cell-free seminal DNA. BMC Genomics 2013;14:288.

204. El Hajj N, Zechner U, Schneider E, Tresch A, Gromoll J, Hahn T, et al. Methylation status of imprinted genes and repetitive elements in sperm DNA from infertile males. Sex Dev 2011;5:60-9.

205. Wu W, Shen O, Qin Y, Niu X, Lu C, Xia Y, et al. Idiopathic male infertility is strongly associated with aberrant promoter methylation of methylenetetrahydrofolate reductase (MTHFR). PLoS One 2010;5:e13884.

206. Boissonnas CC, Jouannet $P$, Jammes H. Epigenetic disorders and male subfertility. Fertil Steril 2013;99:624-31.

207. Carrell DT. Epigenetics of the male gamete. Fertil Steril 2012;97: 267-74.

208. Hammoud SS, Nix DA, Hammoud AO, Gibson M, Cairns BR, Carrell DT. Genome-wide analysis identifies changes in histone retention and epigenetic modifications at developmental and imprinted gene loci in the sperm of infertile men. Hum Reprod 2011;26:2558-69.

209. Liu Z, Zhou S, Liao L, Chen X, Meistrich M, Xu J. Jmjd1a demethylase-regulated histone modification is essential for cAMP-response element modulator-regulated gene expression and spermatogenesis. J Biol Chem 2010;285:2758-70.

210. Yuan S, Tang C, Zhang Y, Wu J, Bao J, Zheng H, et al. mir-34b/c and mir-449a/b/c are required for spermatogenesis, but not for the first cleavage division in mice. Biol Open 2015;4:212-23.

211. Tscherner A, Gilchrist G, Smith N, Blondin P, Gillis D, LaMarre J. MicroRNA-34 family expression in bovine gametes and preimplantation embryos. Reprod Biol Endocrinol 2014;12:85.

212. Abu-Halima $M$, Hammadeh $M$, Backes $C$, Fischer $U$, Leidinger $P$, Lubbad AM, et al. Panel of five microRNAs as potential biomarkers for the diagnosis and assessment of male infertility. Fertil Steril 2014;102:989-97.e1.

213. Abu-Halima M, Backes C, Leidinger P, Keller A, Lubbad AM, Hammadeh $M$, et al. MicroRNA expression profiles in human testicular tissues of infertile men with different histopathologic patterns. Fertil Steril 2014;101:78-86.e2.

214. Conine CC, Moresco JJ, Gu W, Shirayama M, Conte D Jr, Yates JR 
3rd, et al. Argonautes promote male fertility and provide a paternal memory of germline gene expression in C. elegans. Cell 2013;155:1532-44.

215. Zheng G, Dahl JA, Niu Y, Fu Y, Klungland A, Yang YG, et al. Sprouts of RNA epigenetics: the discovery of mammalian RNA demethylases. RNA Biol 2013;10:915-8.

216. Abu-Halima $M$, Hammadeh $M$, Schmitt J, Leidinger $P$, Keller $A$, Meese $E$, et al. Altered microRNA expression profiles of human spermatozoa in patients with different spermatogenic impairments. Fertil Steril 2013;99:1249-55.e16.

217. Wang C, Yang C, Chen X, Yao B, Yang C, Zhu C, et al. Altered profile of seminal plasma microRNAs in the molecular diagnosis of male infertility. Clin Chem 2011;57:1722-31.

218. Forte A, Cipollaro M, Galderisi U. Genetic, epigenetic and stem cell alterations in endometriosis: new insights and potential therapeutic perspectives. Clin Sci (Lond) 2014;126:123-38.

219. Dyson MT, Roqueiro D, Monsivais D, Ercan CM, Pavone ME, Brooks DC, et al. Genome-wide DNA methylation analysis predicts an epigenetic switch for GATA factor expression in endometriosis. PLoS Genet 2014;10:e1004158.

220. Fambrini M, Sorbi F, Bussani C, Cioni R, Sisti G, Andersson KL. Hypermethylation of HOXA10 gene in mid-luteal endometrium from women with ovarian endometriomas. Acta Obstet Gynecol Scand 2013;92:1331-4.

221. Szczepanska M, Wirstlein P, Skrzypczak J, Jagodzinski PP. Expression of HOXA11 in the mid-luteal endometrium from women with endometriosis-associated infertility. Reprod Biol Endocrinol 2012;10:1.

222. Borghese B, Santulli P, Hequet D, Pierre G, de Ziegler D, Vaiman D, et al. Genetic polymorphisms of DNMT3L involved in hypermethylation of chromosomal ends are associated with greater risk of developing ovarian endometriosis. Am J Pathol 2012;180: 1781-6.

223. Hale BJ, Keating AF, Yang CX, Ross JW. Small RNAs: their possible roles in reproductive failure. Adv Exp Med Biol 2015;868:49-79.

224. Jefferson WN, Chevalier DM, Phelps JY, Cantor AM, Padilla-Banks E, Newbold RR, et al. Persistently altered epigenetic marks in the mouse uterus after neonatal estrogen exposure. Mol Endocrinol 2013;27:1666-77.

225. Manosalva I, Gonzalez A. Aging changes the chromatin configuration and histone methylation of mouse oocytes at germinal vesicle stage. Theriogenology 2010;74:1539-47.

226. Zhang H, Jiang X, Zhang Y, Xu B, Hua J, Ma T, et al. MicroRNA 376a regulates follicle assembly by targeting Pcna in fetal and neonatal mouse ovaries. Reproduction 2014;148:43-54.

227. Ball CB, Rodriguez KF, Stumpo DJ, Ribeiro-Neto F, Korach KS, Blackshear PJ, et al. The RNA-binding protein, ZFP36L2, influenc- es ovulation and oocyte maturation. PLoS One 2014;9:e97324.

228. Yuan S, Ortogero N, Wu Q, Zheng H, Yan W. Murine follicular development requires oocyte DICER, but not DROSHA. Biol Reprod 2014;91:39.

229. Xiao G, Xia C, Yang J, Liu J, Du H, Kang X, et al. MiR-133b regulates the expression of the Actin protein TAGLN2 during oocyte growth and maturation: a potential target for infertility therapy. PLoS One 2014;9:e100751.

230. Dong F, Zhang Y, Xia F, Yang Y, Xiong S, Jin L, et al. Genome-wide miRNA profiling of villus and decidua of recurrent spontaneous abortion patients. Reproduction 2014;148:33-41.

231. Szczepanska M, Mostowska A, Wirstlein P, Malejczyk J, Ploski R, Skrzypczak J, et al. Polymorphic variants of DNMT3A and the risk of endometriosis. Eur J Obstet Gynecol Reprod Biol 2013;166:815.

232. Nothnick WB. The role of micro-RNAs in the female reproductive tract. Reproduction 2012;143:559-76.

233. Zhao ZZ, Croft L, Nyholt DR, Chapman B, Treloar SA, Hull ML, et al. Evaluation of polymorphisms in predicted target sites for micro RNAs differentially expressed in endometriosis. Mol Hum Reprod 2011;17:92-103.

234. Laudanski P, Charkiewicz R, Kuzmicki M, Szamatowicz J, Charkiewicz A, Niklinski J. MicroRNAs expression profiling of eutopic proliferative endometrium in women with ovarian endometriosis. Reprod Biol Endocrinol 2013;11:78.

235. Anckaert E, Fair T. DNA methylation reprogramming during oogenesis and interference by reproductive technologies: studies in mouse and bovine models. Reprod Fertil Dev 2015;27:739-54.

236. Petrussa L, Van de Velde H, De Rycke M. Dynamic regulation of DNA methyltransferases in human oocytes and preimplantation embryos after assisted reproductive technologies. Mol Hum Reprod 2014;20:861-74.

237. Rosenbluth EM, Shelton DN, Wells LM, Sparks AE, Van Voorhis BJ. Human embryos secrete microRNAs into culture media: a potential biomarker for implantation. Fertil Steril 2014;101:1493500.

238. Whitelaw N, Bhattacharya S, Hoad G, Horgan GW, Hamilton M, Haggarty P. Epigenetic status in the offspring of spontaneous and assisted conception. Hum Reprod 2014;29:1452-8.

239. Fortier AL, McGraw S, Lopes FL, Niles KM, Landry M, Trasler JM. Modulation of imprinted gene expression following superovulation. Mol Cell Endocrinol 2014;388:51-7.

240. Dimitriadou E, Noutsopoulos D, Markopoulos G, Vlaikou AM, Mantziou S, Traeger-Synodinos J, et al. Abnormal DLK1/MEG3 imprinting correlates with decreased HERV-K methylation after assisted reproduction and preimplantation genetic diagnosis. Stress 2013;16:689-97. 
241. Diaz-Garcia C, Estella C, Perales-Puchalt A, Simon C. Reproductive medicine and inheritance of infertility by offspring: the role of fetal programming. Fertil Steril 2011;96:536-45.

242. Grace KS, Sinclair KD. Assisted reproductive technology, epigenetics, and long-term health: a developmental time bomb still ticking. Semin Reprod Med 2009;27:409-16.

243. Turan N, Katari S, Gerson LF, Chalian R, Foster MW, Gaughan JP, et al. Inter- and intra-individual variation in allele-specific DNA methylation and gene expression in children conceived using assisted reproductive technology. PLoS Genet 2010;6:e1001033.

244. Kochanski A, Merritt TA, Gadzinowski J, Jopek A. The impact of assisted reproductive technologies on the genome and epigenome of the newborn. J Neonatal Perinatal Med 2013;6:101-8.

245. Deshmukh RS, Ostrup O, Strejcek F, Vejlsted M, Lucas-Hahn A, Petersen $B$, et al. Early aberrations in chromatin dynamics in embryos produced under in vitro conditions. Cell Reprogram 2012; 14:225-34.

246. Wu X, Li Y, Xue L, Wang L, Yue Y, Li K, et al. Multiple histone site epigenetic modifications in nuclear transfer and in vitro fertilized bovine embryos. Zygote 2011;19:31-45.

247. Breton A, LE Bourhis D, Audouard C, Vignon X, Lelievre JM. Nuclear profiles of $\mathrm{H} 3$ histones trimethylated on Lys 27 in bovine
(Bos taurus) embryos obtained after in vitro fertilization or somatic cell nuclear transfer. J Reprod Dev 2010;56:379-88.

248. Santos F, Hyslop L, Stojkovic P, Leary C, Murdoch A, Reik W, et al. Evaluation of epigenetic marks in human embryos derived from IVF and ICSI. Hum Reprod 2010;25:2387-95.

249. Siristatidis C, Vogiatzi P, Brachnis N, Liassidou A, Iliodromiti Z, Bettocchi $S$, et al. Review: microRNAs in assisted reproduction and their potential role in IVF failure. In Vivo 2015;29:169-75.

250. Feng R, Sang Q, Zhu Y, Fu W, Liu M, Xu Y, et al. MiRNA-320 in the human follicular fluid is associated with embryo quality in vivo and affects mouse embryonic development in vitro. Sci Rep 2015;5:8689.

251. Karakaya C, Guzeloglu-Kayisli O, Uyar A, Kallen AN, Babayev E, Bozkurt $\mathrm{N}$, et al. Poor ovarian response in women undergoing in vitro fertilization is associated with altered microRNA expression in cumulus cells. Fertil Steril 2015;103:1469-76.e1-3.

252. Galliano D, Pellicer A. MicroRNA and implantation. Fertil Steril 2014;101:1531-44.

253. Zhao Y, Zacur H, Cheadle C, Ning N, Fan J, Vlahos NF. Effect of luteal-phase support on endometrial microRNA expression following controlled ovarian stimulation. Reprod Biol Endocrinol 2012;10:72. 